Biogeosciences, 10, 821-838, 2013

www.biogeosciences.net/10/821/2013/

doi:10.5194/bg-10-821-2013

(C) Author(s) 2013. CC Attribution 3.0 License.

\title{
Stoichiometry constrains microbial response to root exudation- insights from a model and a field experiment in a temperate forest
}

\author{
J. E. Drake ${ }^{1,2}$, B. A. Darby ${ }^{1}$, M.-A. Giasson ${ }^{1}$, M. A. Kramer ${ }^{3}$, R. P. Phillips ${ }^{4}$, and A. C. Finzi ${ }^{1}$ \\ ${ }^{1}$ Department of Biology, Boston University, Boston, MA 02215, USA \\ ${ }^{2}$ Hawkesbury Institute for the Environment, University of Western Sydney, Penrith, NSW 2751, Australia \\ ${ }^{3}$ Department of Mathematics and Statistics, Boston University, Boston, MA, 02215, USA \\ ${ }^{4}$ Department of Biology, Indiana University, Bloomington, IN, 47405, USA
}

Correspondence to: J. E. Drake (je.drake@uws.edu.au)

Received: 23 April 2012 - Published in Biogeosciences Discuss.: 13 June 2012

Revised: 20 December 2012 - Accepted: 28 December 2012 - Published: 7 February 2013

\begin{abstract}
Plant roots release a wide range of chemicals into soils. This process, termed root exudation, is thought to increase the activity of microbes and the exoenzymes they synthesize, leading to accelerated rates of carbon (C) mineralization and nutrient cycling in rhizosphere soils relative to bulk soils. The nitrogen $(\mathrm{N})$ content of microbial biomass and exoenzymes may introduce a stoichiometric constraint on the ability of microbes to effectively utilize the root exudates, particularly if the exudates are rich in $\mathrm{C}$ but low in $\mathrm{N}$. We combined a theoretical model of microbial activity with an exudation experiment to test the hypothesis that the ability of soil microbes to utilize root exudates for the synthesis of additional biomass and exoenzymes is constrained by $\mathrm{N}$ availability. The field experiment simulated exudation by automatically pumping solutions of chemicals often found in root exudates ("exudate mimics") containing $\mathrm{C}$ alone or $\mathrm{C}$ in combination with $\mathrm{N}(\mathrm{C}: \mathrm{N}$ ratio of 10$)$ through microlysimeter "root simulators" into intact forest soils in two 50-day experiments. The delivery of C-only exudate mimics increased microbial respiration but had no effect on microbial biomass or exoenzyme activities. By contrast, experimental delivery of exudate mimics containing both $\mathrm{C}$ and $\mathrm{N}$ significantly increased microbial respiration, microbial biomass, and the activity of exoenzymes that decompose low molecular weight components of soil organic matter (SOM, e.g., cellulose, amino sugars), while decreasing the activity of exoenzymes that degrade high molecular weight SOM (e.g., polyphenols, lignin). The modeling results were consistent with the experiments; simulated delivery of C-only exudates induced microbial N-limitation, which constrained the synthesis of mi-
\end{abstract}

crobial biomass and exoenzymes. Exuding $\mathrm{N}$ as well as $\mathrm{C}$ alleviated this stoichiometric constraint in the model, allowing for increased exoenzyme production, the priming of decomposition, and a net release of $\mathrm{N}$ from SOM (i.e., mineralization). The quantity of $\mathrm{N}$ released from SOM in the model simulations was, under most circumstances, in excess of the $\mathrm{N}$ in the exudate pulse, suggesting that the exudation of $\mathrm{N}$-containing compounds can be a viable strategy for plant- $\mathrm{N}$ acquisition via a priming effect. The experimental and modeling results were consistent with our hypothesis that $\mathrm{N}$-containing compounds in root exudates affect rhizosphere processes by providing substrates for the synthesis of N-rich microbial biomass and exoenzymes. This study suggests that exudate stoichiometry is an important and underappreciated driver of microbial activity in rhizosphere soils.

\section{Introduction}

The transfer of carbon (C) from tree roots to soil is important but poorly understood relative to other processes in the terrestrial C cycle (Grayston et al., 1997; Jones et al., 2004). Healthy and intact roots release a wide variety of chemicals into the surrounding soil (i.e. the rhizosphere), a process termed exudation (Rovira, 1969). Exudation directly couples tree physiology with soil processes, such as microbial physiology, decomposition, and nutrient cycling (Farrar et al., 2003). Exudation rates vary depending on tree species, mycorrhizal associations, and environmental factors affecting tree physiology, such as atmospheric $\mathrm{CO}_{2}$ concentrations, 
temperature, and nutrient supply (Farrar et al., 2003; Phillips et al., 2009). Thus it is possible that tree responses to global change factors will affect exudation and nutrient cycling in soils and thereby influence ecosystem-scale processes such as net primary production and soil C storage (e.g., Langley et al., 2009; Drake et al., 2011; Phillips et al., 2011).

Root exudation has a number of physiological and environmental functions. Plants use membrane-bound ATP-ase $\mathrm{H}^{+}$pumps to create a negative membrane potential that aids in cation uptake; this membrane potential also drives negatively charged compounds out of root cells, including many organic acids such as citrate ${ }^{-3}$, malate $^{-2}$, and oxalate ${ }^{-2}$ (Farrar et al., 2003; Jones et al., 2004). Exudation of these organic acids can mobilize nutrients from soil cation exchange sites, particularly phosphorus in soils with low $\mathrm{pH}$, and help plants avoid aluminum toxicity through chelation (Basu et al., 1994; Jones and Darrah, 1994; Jones, 1998; Ryan et al., 2001; Dakora and Phillips, 2002). Some exuded chemicals also act as signaling molecules or toxic allelochemicals (Grayston et al., 1997; Bertin et al., 2003; Somers et al., 2004). While organic acids and carbohydrates are the dominant chemicals found in root exudates, the few studies that have measured exudate composition have also found a substantial net efflux of amino acids (Bowen, 1969; Rovira, 1969; Smith, 1976; Grayston et al., 1997; Bertin et al., 2003; but see Jones et al., 2009). While bacterial biosensor studies have confirmed that soil microbes access amino acids exuded from roots, the effect of nitrogen $(\mathrm{N})$ compounds in root exudates on microbial activity and biogeochemical fluxes is largely unknown (Jaeger et al., 1999; Vilchez et al., 2000; Espinosa-Urgel and Ramos, 2001).

Here, we focus on the effects of root exudates on microbial activity and their potential to enhance the decomposition of soil organic C and N (SOC and SON). Microbes rapidly absorb exudates and use them for metabolism and exoenzyme production (Jones et al., 1996; Jones, 1998), which stimulates biogeochemical transformations in the rhizosphere relative to bulk soil (Dakora and Phillips, 2002; Paterson, 2003; Phillips et al., 2011). The literature clearly indicates that roots frequently stimulate soil organic matter (SOM) decomposition (i.e., induce a priming effect), particularly when soil $\mathrm{N}$ content is low (Langley et al., 2009; Kaiser et al., 2010; Kuzyakov, 2010; Fontaine et al., 2011). Thus, rhizosphere microbes are apparently able to acquire enough $\mathrm{N}$ to support the synthesis of additional biomass and exoenzymes, which have a low $\mathrm{C}: \mathrm{N}$ ratio and thus a high $\mathrm{N}$ requirement (Elser et al., 2000; Sterner and Elser, 2002; Cleveland and Liptzin, 2007). In this study, we explore the possibility that microbial response to exudates is stoichiometrically constrained by the availability of soil $\mathrm{N}$, and that $\mathrm{N}$ compounds in exudates can alleviate this constraint.

We investigated the effects of root exudation on the activity of soil microbes and exoenzymes using a theoretical model of decomposition and a field experiment. We simulated microbial response to exudate delivery using a model of microbial physiology and decomposition developed from previous work (e.g., Allison et al., 2010; Schimel and Weintraub, 2003). We tested these model predictions in a field experiment, where we pumped solutions of chemicals often found in root exudates ("exudate mimics") through microlysimeters in an attempt to simulate exudation from a root. Using this combined model-experiment approach, we tested the hypothesis that the ability of soil microbes to utilize root exudates for the synthesis of additional biomass and exoenzymes is constrained by $\mathrm{N}$ availability. We predict that the exudation of $\mathrm{N}$ as well as $\mathrm{C}$ will elicit a larger rhizosphere response (i.e., increase in microbial biomass, respiration, and exoenzyme activities) relative to the exudation of $\mathrm{C}$ alone.

\section{Methods}

\subsection{Theoretical modeling of decomposition}

We used an existing modeling framework to explore how decomposition may respond to the delivery of root exudates (Schimel and Weintraub, 2003). This theoretical model operates on the scale of a gram of soil with an hourly time step and has no environmental drivers. The purpose of the model was to explore theoretical linkages between exoenzymatic depolymerization of soil organic matter (SOM), microbial physiology, exudation, and stoichiometry ( $\mathrm{C}: \mathrm{N}$ ratio), not to quantitatively predict decomposition in a particular study location. Thus, this model operates on a smaller scale of biological organization relative to ecosystem scale biogeochemical models. This model explicitly simulates microbial production of exoenzymes that depolymerize complex and insoluble SOM into soluble monomers that are available for microbial uptake (Fig. 1a). Thus, this model incorporates mechanisms related to microbial physiology and exoenzyme activity that are known to control decomposition in soils (Schimel and Bennett, 2004; Blagodatsky et al., 2010), but differs from common decomposition models that assume SOM pools decompose at a characteristic first-order rate, modified by empirical temperature and moisture functions (e.g., the CENTURY and RothC models; Parton et al., 1988, 1993; Coleman et al., 1997; Zimmermann et al., 2007). This model has been described, evaluated for stability, and used to simulate the response of microbial respiration to additions of $\mathrm{C}$ and $\mathrm{N}$ (Schimel and Weintraub, 2003). Subsequent investigations have utilized models of similar structure to evaluate the consequences of microbial acclimation to warming (Allison et al., 2010), simulate laboratory isotopic tracer experiments (Blagodatsky et al., 2010), and incorporate additional complexity such as multiple exoenzyme pools (Moorhead et al., 2012) and N-trace gas emissions (Blagodatsky et al., 2011). Here, we use the model to make predictions that are then tested experimentally with a field experiment, consistent with identified research needs (Treseder et al., 2012). The decomposition model is described in detail in Appendix A. 


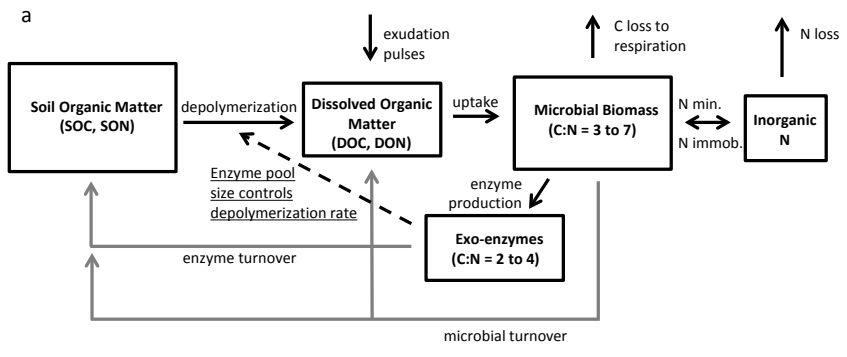

b

Fig. 1. Structure of the decomposition model (a) and graphical description of how the modeling motivated the field experiment (b). In (a), solid arrows refer to fluxes and boxes refer to pools. The turnover of dead microbes and inactivated enzymes into soil organic matter and dissolved organic matter pools are shown as grey arrows, and the importance of enzymes in depolymerizing soil organic matter into dissolved pools is shown with a dotted arrow. "N min." refers to $\mathrm{N}$ mineralization, and " $\mathrm{N}$ immob." refers to the immobilization of inorganic $\mathrm{N}$ into microbial biomass. A detailed description of the model equations can be found in Appendix A.

In brief, the model is composed of five pools connected by fluxes (Fig. 1a). SOM is depolymerized into dissolved organic matter (DOM) depending on the quantity of exoenzymes in a reverse Michaelis-Menten manner as in Schimel and Weintraub (2003). DOM is taken up by microbial biomass according to Michaelis-Menten kinetics as in Allison et al. (2010) and microbes use these resources to fuel exoenzyme and biomass production according to first-order equations, each of which has a respiratory cost determined by a substrate use efficiency (SUE) parameter. When $\mathrm{N}$ demand exceeds $\mathrm{N}$ supply (i.e., under $\mathrm{N}$-limitation), the surplus $\mathrm{C}$ is mineralized as overflow metabolism; when $\mathrm{C}$ demand exceeds $\mathrm{C}$ supply (i.e., under $\mathrm{C}$-limitation), the surplus $\mathrm{N}$ is mineralized (as in Schimel and Weintraub, 2003). Microbes and enzymes turn over with first-order kinetics and the resulting material re-enters SOM and DOM pools (as in Schimel and Weintraub, 2003). The model does not explicitly include a plant or root component; we incorporated the root process of interest (i.e., exudation) by adding material to the DOM pools at user-defined time points. It would be necessary to explicitly include a plant component to model ecosystem scale processes (e.g., soil $\mathrm{CO}_{2}$ flux, net primary production), as stand-level attributes such as fine-root crop would introduce feedbacks between SOM pools, nutrient availability, and mi- crobial biomass. However, our interest was focused on microbial responses to exudates, which is a mechanism that operates on a small scale of inference (e.g., a gram of soil); thus we chose not to introduce the complexity of an explicit plant component. We made four changes to the model of Schimel and Weintraub (2003): we included Michaelis-Menten kinetics for microbial uptake of DOM, fixed an error in the equation governing inorganic $\mathrm{N}$ immobilization, introduced a flux by which inorganic $\mathrm{N}$ was removed from the model, and made enzyme production proportional to microbial biomass as in Allison et al. (2010). These changes are discussed in detail in Appendix A.

Model simulations were used to test the theoretical underpinnings of the hypothesis and motivate the design of the field experiments that are described below (Fig. 1b). We explored how the modeled response to exudate pulses varied with the stoichiometry of the system; that is, we ran the model with varying $\mathrm{C}: \mathrm{N}$ ratios of exudates, SOM, exoenzymes, and microbes (Fig. 2). In these simulations, we paid particular interest to the conditions when the additional $\mathrm{N}$ mineralized from SOM following an exudate addition exceeded the amount of $\mathrm{N}$ exuded, as this would indicate that roots could achieve a net "return on investment" for $\mathrm{N}$ through a priming mechanism. We also performed a sensitivity analysis to determine which parameters most affected the response of net mineralization and SOM decomposition to exudate pulses (Table 1). Parameter values were taken from the literature (Schimel and Weintraub, 2003; Allison et al., 2010), and we assessed model sensitivity to halving and doubling these values (Table 1). In our simulations, however, SOM and exoenzyme $\mathrm{C}: \mathrm{N}$ ratios were limited to biologically realistic ranges of 10 to 30 (Batjes, 1996; Aitkenhead and McDowell, 2000), and 2 to 4, respectively (Sterner and Elser, 2002). For each parameter set, we quantified the additional $\mathrm{N}$ depolymerized and mineralized from SOM because of an exudate pulse by integrating the response variable after the pulse relative to a model run with identical parameters but no exudate pulse. Sensitivity was calculated as in Allison et al. (2010) in a way that normalizes the change in output relative to the size of the change in parameterization:

Sensitivity $=\frac{|\log | \text { high output }|-\log | \text { low output }||}{|\log | \text { high parameter value }|-\log | \operatorname{low} \text { parameter value }||}$

\subsection{Site of field experiments}

After the model provided theoretical support for the hypothesis (Sect. 3.1, Modeling, below), we conducted experimental tests using a series of field experiments. These experiments were conducted in the Prospect Hill tract of Harvard Forest, a Long Term Ecological Research (LTER) site in central Massachusetts, USA. This site was comprised of a mixed deciduous forest primarily dominated by red oak (Quercus rubra L.) and red maple (Acer rubrum L.) recovering from a hurricane disturbance in 1938. The soil was derived from glacial till and was a well-aerated fine sandy loam, classified 
Table 1. Parameter sensitivity analysis of modeled net $\mathrm{N}$ mineralization and SOM decomposition following an exudate pulse.

\begin{tabular}{|c|c|c|c|c|c|c|}
\hline Parameter & Description & $\begin{array}{l}\text { Low } \\
\text { value }\end{array}$ & $\begin{array}{r}\text { Moderate } \\
\text { value }\end{array}$ & $\begin{array}{l}\text { High } \\
\text { value }\end{array}$ & $\begin{array}{r}\text { Sensitivity } \\
\text { of net } \mathrm{N} \\
\text { mineralization }\end{array}$ & $\begin{array}{r}\text { Sensitivity of } \\
\text { decomposition } \\
\text { of SOM }\end{array}$ \\
\hline$K_{1}$ & Decay rate for exoenzymes & 0.025 & 0.05 & 0.1 & 1.35 & 1.35 \\
\hline Exudate $\mathrm{C}: \mathrm{N}$ & $\mathrm{C}: \mathrm{N}$ ratio of exudate pulse & 25 & 50 & 100 & 1.00 & 0.50 \\
\hline Exudate pulse size & Quantity of exudates delivered ( $\mu \mathrm{g} C)$ & 50 & 100 & 200 & 0.99 & 0.57 \\
\hline SUE & Substrate use efficiency & 0.25 & 0.5 & 1 & 0.77 & 1.77 \\
\hline$K_{\mathrm{r}}$ & $\begin{array}{l}\text { Proportion of microbial biomass recycled into } \\
\text { DOM pools }\end{array}$ & 0.43 & 0.85 & 1 & 0.70 & 0.20 \\
\hline$K_{\text {ep }}$ & $\begin{array}{l}\text { Proportionality of exoenzyme production } \\
\text { and microbial biomass }\end{array}$ & 0.00025 & 0.0005 & 0.001 & 0.57 & 1.31 \\
\hline Soil C: N & $\mathrm{C}: \mathrm{N}$ ratio of $\mathrm{SOM}$ & 10 & 20 & 30 & 0.42 & 0.11 \\
\hline$K_{\mathrm{m}}$ & Microbial maintenance rate & 0.005 & 0.01 & 0.02 & 0.31 & 0.43 \\
\hline$K_{\mathrm{t}}$ & Decay rate for microbes & 0.006 & 0.012 & 0.024 & 0.27 & 0.56 \\
\hline Exoenzyme $\mathrm{C}: \mathrm{N}$ & $\mathrm{C}: \mathrm{N}$ ratio of exoenzymes & 2 & 3 & 4 & 0.24 & 0.03 \\
\hline Microbe $\mathrm{C}: \mathrm{N}$ & $\mathrm{C}: \mathrm{N}$ of microbial biomass & 3.5 & 7 & 14 & 0.15 & 0.58 \\
\hline
\end{tabular}

as a Typic Dystrochrept (Borken et al., 2006b). Soil pH (1:1 soil : water extractions) was $\sim 4.0$ (Bowden et al., 1998; Brzostek and Finzi, 2011), the bulk density of the A horizon was $0.7 \mathrm{~g} \mathrm{~cm}^{-3}$ (Borken et al., 2006a), and fine root biomass at this site was $\sim 300 \mathrm{~g} \mathrm{C} \mathrm{m}^{-2}$, which is comparable with the temperate forest average (Gaudinski et al., 2000; Finer et al., 2011). We sampled soil in 18 locations within $100 \mathrm{~m}$ of the study site to characterize $\mathrm{C}$ and $\mathrm{N}$ content. Soils were cored to $15-\mathrm{cm}$ depth with a bulk density sampler (AMS, American Falls, South Dakota, USA), passed through a 2-mm sieve, dried, and analyzed for $\mathrm{C}$ and $\mathrm{N}$ on an elemental analyzer (NC2500; CE Elantech, Lakewood, New Jersey, USA). The soil had a $\mathrm{C}$ content of $5.1 \pm 1.4 \%$ (standard deviation), an $\mathrm{N}$ content of $0.22 \pm 0.05 \%$, and a $\mathrm{C}: \mathrm{N}$ ratio of $22.8 \pm 2.5$. Long-term meteorological observations at this site (19642010) record a mean annual temperature of $7.5^{\circ} \mathrm{C}$ and evenly distributed precipitation throughout the year with a mean annual value of $1120 \mathrm{~mm}$ (Boose and Gould, 1999; Boose, 2001). This particular forest location has been the site of extensive research regarding the controls of $\mathrm{CO}_{2}$ and other trace gas fluxes from soil (Davidson et al., 1998, 2006; Savage and Davidson, 2001; Borken et al., 2003, 2006a; Savage et al., 2009). Net ecosystem exchange (NEE) of $\mathrm{CO}_{2}$ and $\mathrm{H}_{2} \mathrm{O}$ has been measured since 1991 at the nearby Environmental Measurement Site; these data were used to determine the timing of exudation treatments (Munger and Wofsy, 1999; Urbanski et al., 2007). We scheduled the exudation treatments to occur during periods with high rates of net $\mathrm{CO}_{2}$ uptake, with the assumption that root exudation is high during periods of high photosynthetic C-uptake (Dilkes et al., 2004; Phillips and Fahey, 2005).

\subsection{Treatments mimicking root exudation}

We simulated root exudation in the field by pumping solutions containing compounds typically found in root exudates (hereafter, "exudate mimics") through microlysimeters inserted vertically into the top $10 \mathrm{~cm}$ of mineral soil (Rhizon soil solution samplers, Rhizosphere Research Products, Wageningen, The Netherlands; see lab study by Kuzyakov et al., 2007). These microlysimeters were installed in a 3 by $3 \mathrm{~m}$ area within the previously described forest stand. The cylindrical microlysimeters were $10 \mathrm{~cm}$ long and $2.5 \mathrm{~mm}$ in diameter with a mean pore size of $0.15 \mu \mathrm{m}$. Solutions were pumped through the microlysimeters using peristaltic pumps (Model 205U, Watson-Marlow, Wilmington, Massachusetts, USA) and 0.25-mm diameter tubing (Marprene, WatsonMarlow) daily from 11:00-11:15 h and 13:00-13:15 h using automatic timers (Model DT520CL, Intermatic Inc., Spring Grove, Illinois, USA) at a flow rate of $0.06 \mathrm{~mL} \mathrm{~min}^{-1}$. The exudate delivery system was originally designed and tested at the Duke Free Air $\mathrm{CO}_{2}$ Enrichment site (R. P. Phillips, personal communication, 2007). We elected to use two daily pulses because our system of pumps and tubing could not operate accurately when run continuously at the extremely low flow rates that would be required to avoid large water additions. The main advantage of this field-based microlysimeter approach is the delivery of small quantities of exudate mimics to intact soils that are subject to the full suite of biotic and abiotic factors that occur in the field. This approach differs from most experiments that have added compounds to soil, often in large single doses or to disturbed soils in the lab (e.g., De Nobili et al., 2001; Vance and Chapin, 2001; Fontaine et al., 2004; Brant et al., 2006a; Hamer and Marschner, 2005).

This automated system was used to deliver solutions to forest soils in four treatments: a disturbance control, a water control, a C-only addition, and a $\mathrm{C}+\mathrm{N}$ addition. For the disturbance control, we installed microlysimeters vertically in the soil and added no other treatment. The water control consisted of microlysimeter installation and automated additions of water. Comparisons between the water control and the disturbance control thus capture any direct effect of water 

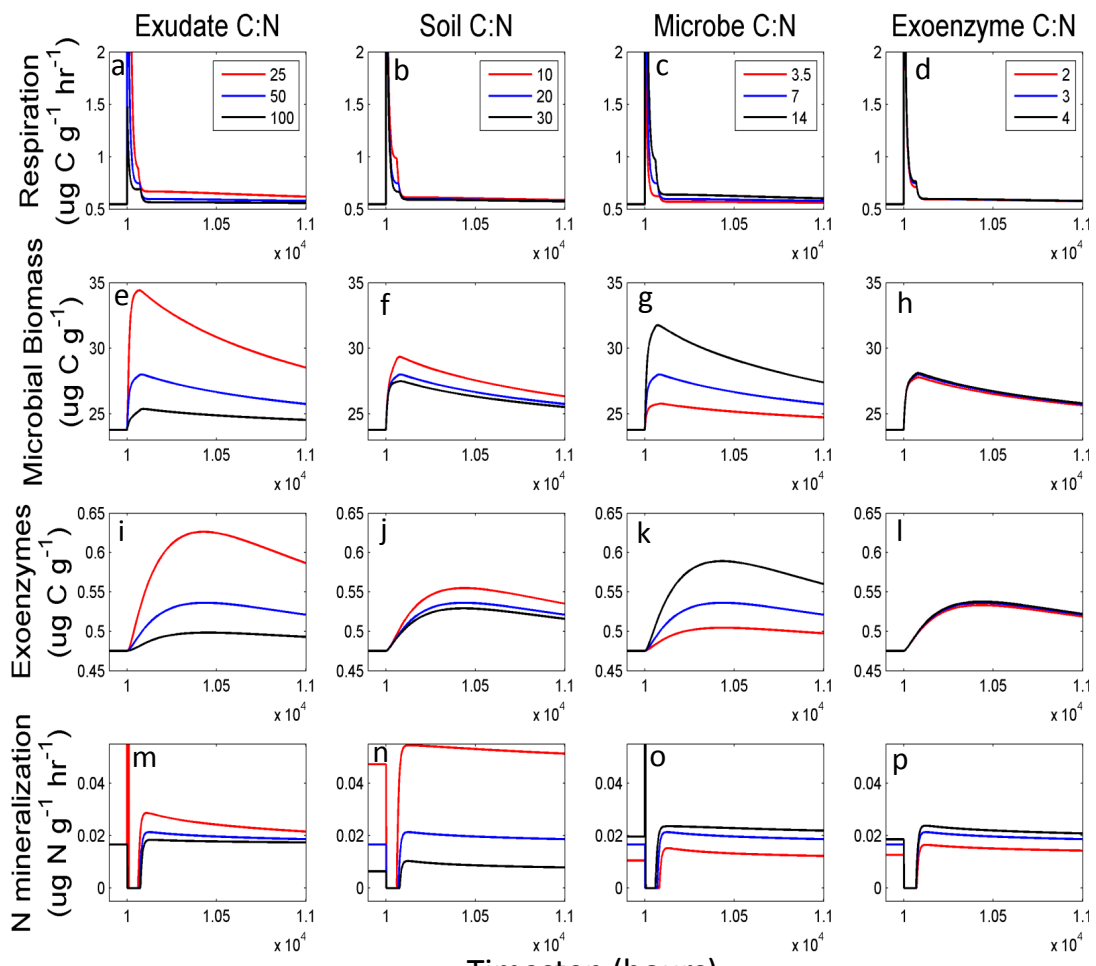

Fig. 2. Model responses of respiration, microbial biomass, soil enzymes, and $\mathrm{N}$ mineralization to an exudate pulse depend on stoichiometry. The model was "spun-up" for $1 \times 10^{4}$ time steps to reach steady-state and a pulse of DOC and DON was added. The model was run at the moderate value for each parameter (Table 1) except the parameter that was varied. In general, the response to an exudate pulse was greatest when $\mathrm{N}$ availability was high (low exudate $\mathrm{C}: \mathrm{N}$ and low soil $\mathrm{C}: \mathrm{N}$ ) and microbial $\mathrm{N}$ demand was low (high microbial $\mathrm{C}: \mathrm{N}$ and high enzyme $\mathrm{C}: \mathrm{N})$.

additions on microbial activity. The $\mathrm{C}$-only treatment consisted of a $500 \mathrm{mg} \mathrm{C} \mathrm{L}^{-1}$ solution comprised of $75 \%$ organic acids and $25 \%$ carbohydrates. A stock solution for this treatment was made by dissolving $1.25 \mathrm{~g}$ citric acid, $2.47 \mathrm{~g}$ oxalic acid, $1.13 \mathrm{~g}$ fumaric acid, $1.35 \mathrm{~g}$ malonic acid, and $1.56 \mathrm{~g}$ glucose in one liter of water; this stock solution was diluted $1: 10$ before use. These compounds reflect our best estimate of exudate chemistry from the relatively few literature studies on this subject (Bowen, 1969; Rovira, 1969; Smith, 1976; Bertin et al., 2003; Jones et al., 2009). This solution contains a mix of relatively reduced and energy-rich chemicals (e.g., glucose) along with more oxidized and energy-poor chemicals (e.g., oxalic acid); the weighted-average degree of reduction was 2.8 with a theoretical biomass yield of 0.37 (von Stockar et al., 2006). The $\mathrm{C}+\mathrm{N}$ treatment consisted of the same delivery solution used for the $\mathrm{C}$-only treatment, plus $50 \mathrm{mg} \mathrm{N} \mathrm{L}^{-1}$ as $\mathrm{NH}_{4} \mathrm{Cl}$, yielding a solution with a $\mathrm{C}: \mathrm{N}$ ratio of 10. We used $\mathrm{NH}_{4} \mathrm{Cl}$ instead of an organic $\mathrm{N}$ source to test specifically whether $\mathrm{N}$ availability constrains microbial responses to $\mathrm{C}$ exudates. We acknowledge that amino acids rather than $\mathrm{NH}_{4}^{+}$are exuded from roots, but our objective was to test the effect of exudate stoichiometry on rhizosphere processes; had we used an organic $\mathrm{N}$ compound we could not meaningfully compare the results of the C-only treatments to those containing both $\mathrm{C}$ and $\mathrm{N}$, as $\mathrm{C}$ content would have been confounded with $\mathrm{N}$ content. We chose not to implement a separate $\mathrm{N}$ addition treatment. Adding this additional treatment would have required additional expensive peristaltic pumps, and plant roots do not exude $\mathrm{N}$ in the absence of C (Bowen, 1969; Smith, 1976; Jones et al., 2009). While such a treatment may have been useful to specifically identify a $\mathrm{C}$ by $\mathrm{N}$ interaction, we excluded this treatment because it is not biologically realistic. The water, $\mathrm{C}$-only, and $\mathrm{C}+\mathrm{N}$ treatment solutions were replaced weekly to minimize the effects of contamination. These concentrations and the delivery flow rate were chosen to mimic rates of exudation observed for four temperate tree species in this region $(\mathrm{Br}-$ zostek et al., 2012). We delivered these solutions to ten microlysimeters per treatment $(n=10)$.

Exudates were delivered from 6 June to 25 July 2011 (50 days) and from 8 August to 26 September 2011 (50 days). The first experiment was timed to capture the early summer period after leaf expansion, and the second experiment was timed to capture the mid-late summer period prior to leaf coloration (Richardson and O'Keefe, 2009). Net ecosystem 
exchange of $\mathrm{CO}_{2}$ is typically strongly positive during these periods, indicating net ecosystem C uptake (Fig. B1).

\subsection{Soil sampling}

We collected soil in contact with each microlysimeter on 25 July and 26 September 2011 using sharpened aluminum tubes measuring $13.5 \mathrm{~mm}$ in diameter and $10 \mathrm{~cm}$ in length. A test injection with blue dye demonstrated that a $500 \mu \mathrm{L}$ injection twice a day delivered the solution to a cylinder of soil $\sim 5 \mathrm{~mm}$ in radius from the microlysimeter (R. P. Phillips, personal observation, 2007), so the small soil cores adequately sampled the influenced soil with minimal contamination of bulk soil. The soil samples were transported to Boston University in a cooler, stored overnight at $4{ }^{\circ} \mathrm{C}$, and processed the following day (Sect. 2.5). Soils were homogenized and roots were removed by hand.

\subsection{Soil process rates}

We measured a number of processes related to the activity of soil microbes to assess the degree to which the exudation treatments influenced heterotrophic activity. We measured microbial respiration, microbial biomass, proteolytic rates, and extracellular enzyme activities.

The rate of $\mathrm{CO}_{2}$ production by heterotrophs (hereafter, "microbial respiration") for each soil sample was measured in the lab using short-term incubations; $2 \mathrm{~g}$ of soil was placed in a septum-sealed $500 \mathrm{~mL}$ glass jar and incubated at lab temperature $\left(\sim 23^{\circ} \mathrm{C}\right)$. Three headspace samples $(10 \mathrm{~mL})$ were taken at 2-h intervals and injected into an infrared gas analyzer (Model EGM-4; PP-Systems, Amesbury, Massachusetts, USA) to determine the concentration of $\mathrm{CO}_{2}$. These concentrations increased at a linear rate for all samples (minimum $r^{2}=0.93$, average $r^{2}=0.98$ ). The rate of $\mathrm{CO}_{2}$ production per $\mathrm{g}$ dry soil was calculated from these slopes, the jar volume, soil mass, and soil gravimetric water content.

Microbial biomass was measured for each sample using the substrate-induced respiration (SIR) method for both sampling dates (25 July and 26 September 2011) and the chloroform-fumigation extraction (CFE) method for the second sampling date only (26 September 2011). The SIR method was performed just after the microbial respiration measurements described above by adding a glucose solution to each soil jar to achieve an addition of $2 \mathrm{~mL}$ and $20 \mathrm{mg} g l u c o s e$ soil $^{-1}$ (Harden et al., 1993). The glucose solution was added drop by drop over the surface of the soil and the jars were shaken by hand to achieve a well-mixed delivery of glucose. After waiting one hour, the rate of $\mathrm{CO}_{2}$ production was measured using three headspace samples taken at hourly intervals using the same procedure as described above for microbial respiration. The rate of $\mathrm{CO}_{2}$ production following glucose addition was linear for all samples (minimum $r^{2}=0.98$, average $r^{2}=0.99$ ). Maximum rates of SIR were converted to microbial biomass using a previously pub- lished equation (Anderson and Domsch, 1978; Phillips et al., 2011). Microbial biomass $N$ was measured using the CFE procedure assuming an extraction efficiency $\left(k_{\mathrm{n}}\right)$ value of 0.68 (Gallardo and Schlesinger, 1990).

The activity of soil proteolytic enzymes was measured as the gross rate of increase in free amino acids (OPAME method of Jones et al., 2002) over a 4-h incubation using $2 \mathrm{~g}$ of soil exactly as previously described (Watanabe and Hayano, 1995; Lipson et al., 1999; Brzostek and Finzi, 2012; Brzostek and Finzi, 2011). This method is based on the principal that proteins are amino acid polymers, and depolymerization into amino acid monomers controls the rate of protein breakdown into bioavailable forms. This conversion of organic $\mathrm{N}$ polymers into soluble amino acid monomers is hereafter referred to as proteolysis; this process has been characterized as a rate-limiting step for the decomposition of SOM (Schimel and Bennett, 2004).

We measured the activity of extracellular enzymes related to phosphorus mineralization (acid phosphatase, herein abbreviated as AP) and the decomposition of amino sugars $(\beta-1,4-\mathrm{N}$-acetyl-glucosaminidase; NAG), cellulose $(\beta$ 1,4-glucosidase; BG), and lignin (peroxidase and phenol oxidase; PerOx and PhenOx, respectively). The activity of these exoenzymes were measured by mixing $1 \mathrm{~g}$ of soil with $100 \mathrm{~mL}$ of $50 \mathrm{mM}$ sodium acetate buffer adjusted to $\mathrm{pH}=5.0$. The samples were continuously stirred and twenty-four $200 \mu \mathrm{L}$ aliquots of the suspension were transferred to 96-well microplates; exoenzyme activities were subsequently measured exactly as described previously (Finzi et al., 2006) using 96-well plate readers (VersaMax and SpectraMax Gemini XS, Molecular Devices, Sunnydale, California, USA) and expressed as nmol substrate utilized $\mathrm{g}^{-1}$ dry soil $\mathrm{h}^{-1}$. Lignolytic enzymes (PerOx and PhenOx) were measured colorimetrically using L-dihydroxyphenylalanine (L-DOPA) substrate with a 4-h incubation; all other enzymes were measured fluorometrically using substrates linked to a fluorescent tag (4-methylumbelliferone) with a 2-h incubation.

We used the decomposition model (described above, Sect. 2.1) to predict the expected response of microbial biomass to the exudation treatments. That is, we evaluated if the model predictions for a 50-day experiment with twicedaily exudate pulses agreed with the experimental results. The model was parameterized using established values for all parameters (Table 1; Schimel and Weintraub, 2003; Allison et al., 2010) and two exudate pulses were delivered per day, which matched the field experiments. Model runs were performed with no exudate treatment, a C-only treatment, or treatment with $\mathrm{C}$ and $\mathrm{N}$ together at a $\mathrm{C}: \mathrm{N}$ ratio of 10 ; these simulations were developed to match the experimental treatments. 


\subsection{Statistical analyses}

The exudation field experiments consisted of a completely randomized design with ten replicates for each of four categories of treatments (disturbance control, water, C-only, and $\mathrm{C}+\mathrm{N})$. Results were analyzed in the GLM procedure of the SAS system (SAS 9.1; SAS Institute Inc., Cary, North Carolina, USA). Treatment was included as a fixed effect. As there were two separate experiments, the mean of each experiment and an experiment by interaction term were included as random effects. When the main effect of treatment was statistically significant, statistical comparisons of individual exudation treatments were performed using the Duncan's multiple range post-hoc test, which reduces the number of individual comparisons and thus partially controls the experiment-wise error rate (Duncan, 1955; Littell et al., 2002). The assumptions that model residuals were normally distributed with mean zero and constant variance were met in all cases; no transformations were necessary.

In addition to analyzing the data for each enzyme activity assay as above, we summarized the effects of exudation treatments across all enzymes using meta-analysis (MetaWin v.2.1; Rosenberg et al., 2000). While meta-analysis is frequently used to synthesize data from multiple experiments (e.g., Rustad et al., 2001; Ainsworth and Long, 2005), it can also be used to synthesize treatment effects on soil enzymes within single studies (Hedges and Olkin, 1985; Saiya-Cork et al., 2002). We calculated the natural log of the response ratio (i.e., $\ln$ (treatment value/disturbance control value)) and the variance around this ratio for each enzyme activity measurement. We calculated the effect size and bias-corrected bootstrapped $95 \%$ confidence intervals for the mean response of soil enzyme activities to water, $\mathrm{C}$-only, and $\mathrm{C}+\mathrm{N}$ exudation treatments. For this analysis, the enzymes were grouped into hydrolytic enzymes that decompose low molecular weight substrates (proteolytic enzymes, AP, NAG, and BG) and oxidative enzymes that decompose high molecular weight substrates (PerOx and PhenOx; Table 2). Positive response ratios indicate that exudation treatments increased enzyme activities relative to unamended disturbance controls.

\section{Results}

\subsection{Modeling}

Microbial respiration increased in two distinct phases following a modeled exudate pulse of DOC and DON; there was an abrupt increase in respiration associated with the construction of new microbial biomass (Fig. 2e-h) and exoenzymes (Fig. 2i-1), followed by a small but sustained increase in the maintenance respiration of microbial biomass (Fig. 2a-d). The increase in the exoenzyme pool size following an exudate pulse affected the decomposition of SOM and $\mathrm{N}$ mineralization in three phases. Initially, there was an abrupt spike

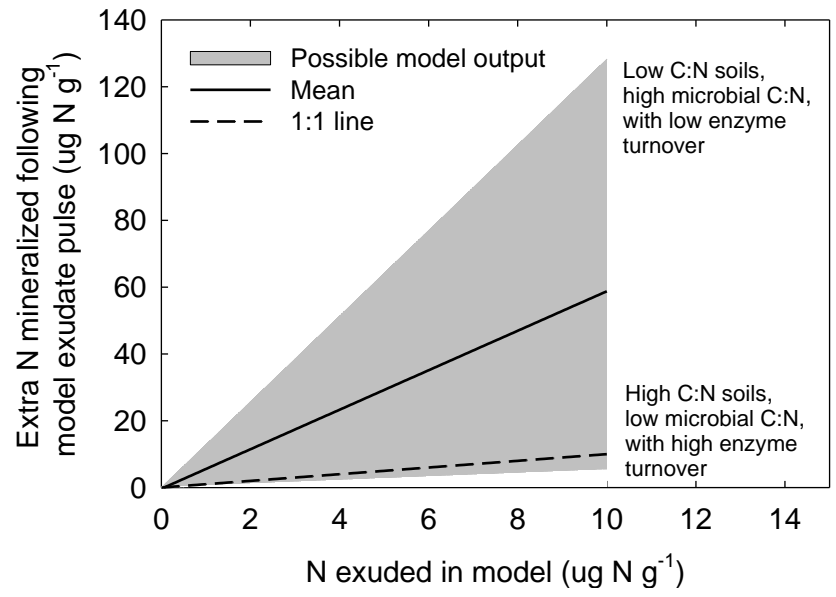

Fig. 3. Model results of the additional $\mathrm{N}$ mineralized following exudate pulses of varying $\mathrm{N}$ content. The cumulative extra $\mathrm{N}$ mineralized following an exudate pulse increased with increasing $\mathrm{N}$ exudation (solid line, $y=5.9 x-0.4$ ) and was generally above the $1: 1$ line (dashed line). $\mathrm{N}$ exudation increased exoenzyme activity which released $\mathrm{N}$ from SON. The grey area indicates possible model output, depending on parameter values.

of $\mathrm{N}$ mineralization when the DON additions briefly pushed microbes into a state of C-limitation (e.g. red line in Fig. 2m, black line in Fig. 2o). This initial phase was not observed in all of the model runs. Next, $\mathrm{N}$ mineralization dropped to zero while the microbes were utilizing all available $\mathrm{N}$ to produce biomass and exoenzymes (Fig. $2 \mathrm{~m}-\mathrm{p}$ ). Thus, modeled exudation briefly stimulated microbial uptake of organic and inorganic $\mathrm{N}$ and reduced the $\mathrm{N}$ that would be available to plant roots. Finally, the microbes returned to a state of $\mathrm{C}$ limitation and began mineralizing N. During this period, rates of N mineralization and the depolymerization of SON into DON were higher than the rates preceding the pulse (Fig. $2 \mathrm{~m}-\mathrm{p}$ ). Thus, the model predicts that an exudate pulse can theoretically increase the amount of organic and inorganic $\mathrm{N}$ available for root uptake, after a brief period of microbial immobilization. In the long term, all pools and fluxes eventually returned to pre-exudate equilibrium values.

While this pattern was generally consistent across model runs, the stoichiometry of the system affected the microbial and enzymatic response to exudate delivery. The stoichiometry of the exudate pulse itself had the largest effect on microbial and exoenzyme activity (Fig. 2a, e, i, m); exuding $\mathrm{N}$ along with $\mathrm{C}$ strongly stimulated the microbial and exoenzymatic response. A larger response in microbial biomass and exoenzyme pools was observed when the $\mathrm{N}$-supply potential of the system was high (i.e., a low soil $\mathrm{C}: \mathrm{N}$ ratio and low exudate $\mathrm{C}: \mathrm{N}$ ) and when microbial $\mathrm{N}$ demand was low (i.e., with high microbial $\mathrm{C}: \mathrm{N}$ and high enzyme $\mathrm{C}: \mathrm{N}$ ratios). Varying microbial $\mathrm{C}: \mathrm{N}$ also affected the modeled response to an exudate pulse (Fig. 2c, g, k, o), while varying 
Table 2. Measured activity of soil exoenzymes and availability of soil amino acids in response to exudate mimic delivery to intact forest soils in the field. Values reflect the mean $( \pm \mathrm{SE})$ of 10 replicates. $T$ indicates a significant effect of exudation treatment, $E$ indicates a significant difference between the two experiments, and $T^{*} E$ indicates a significant interaction.

\begin{tabular}{|c|c|c|c|c|c|c|c|c|}
\hline \multirow[b]{2}{*}{ Experiment } & \multirow[b]{2}{*}{ Treatment } & \multicolumn{4}{|c|}{ Enzymes that decompose low molecular weight substrates } & \multirow[b]{2}{*}{$\begin{array}{l}\text { Amino acid } \\
\text { pool size }\end{array}$} & \multicolumn{2}{|c|}{$\begin{array}{l}\text { Enzymes that decompose high } \\
\text { molecular weight substrates }\end{array}$} \\
\hline & & AP & NAG & BG & Proteolytic & & PhenOx & PerOx \\
\hline & & $\mathrm{nmolg}^{-1} \mathrm{~h}^{-1}$ & $\mathrm{nmolg}^{-1} \mathrm{~h}^{-1}$ & $\mathrm{nmol} \mathrm{g}^{-1} \mathrm{~h}^{-1}$ & $\mu g \mathrm{Ng}^{-1} 4 \mathrm{~h}^{-1}$ & $\mu g \mathrm{Ng}^{-1}$ & $\mathrm{nmolg}^{-1} \mathrm{~h}^{-1}$ & $\mathrm{nmol} \mathrm{g}^{-1} \mathrm{~h}^{-1}$ \\
\hline 1 & Control & $291(20)^{\mathrm{a}}$ & $19.3(3.4)^{\mathrm{a}}$ & $123(8)^{\mathrm{a}}$ & $8.9(0.7)^{\mathrm{a}, \mathrm{b}}$ & $4.6(0.5)^{\mathrm{a}}$ & $696(57)^{\mathrm{a}}$ & $473(62)^{\mathrm{a}}$ \\
\hline 1 & Water & $250(23)^{\mathrm{a}}$ & $17.6(3.2)^{\mathrm{a}}$ & $114(14)^{\mathrm{a}}$ & $6.8(1.4)^{\mathrm{b}}$ & $4.9(0.4)^{\mathrm{a}}$ & $698(31)^{\mathrm{a}}$ & $697(47)^{\mathrm{b}}$ \\
\hline 1 & $\mathrm{C}$ & $258(10)^{\mathrm{a}}$ & $41.7(3.4)^{b}$ & $122(13)^{\mathrm{a}}$ & $9.2(1.3)^{\mathrm{a}, \mathrm{b}}$ & $5.8(0.7)^{\mathrm{a}}$ & $580(57)^{\mathrm{a}}$ & $423(35)^{\mathrm{a}, \mathrm{c}}$ \\
\hline 1 & $\mathrm{C}+\mathrm{N}$ & $530(57)^{\mathrm{b}}$ & $54.2(6.7)^{b}$ & $159(14)^{b}$ & $12.9(1.9)^{\mathrm{a}}$ & $11.5(1)^{b}$ & $399(73)^{b}$ & $302(54)^{\mathrm{c}}$ \\
\hline 2 & Control & $292(20)^{\mathrm{a}}$ & $11.1(1.6)^{\mathrm{a}}$ & $102(16)^{a}$ & $5.3(0.7)^{\mathrm{a}}$ & $8.4(0.6)^{\mathrm{a}}$ & $620(67)^{\mathrm{a}}$ & $909(146)^{\mathrm{a}}$ \\
\hline 2 & Water & $299(32)^{\mathrm{a}}$ & $52.9(7.3)^{b}$ & $103(8)^{\mathrm{a}}$ & $9.3(1.1)^{\mathrm{b}}$ & $7.1(0.9)^{\mathrm{a}}$ & $470(75)^{\mathrm{a}}$ & $575(102)^{b}$ \\
\hline 2 & $\mathrm{C}$ & $348(31)^{\mathrm{a}}$ & $20.5(2.6)^{\mathrm{a}}$ & $116(11)^{\mathrm{a}}$ & $7.3(0.6)^{\mathrm{a}, \mathrm{b}}$ & $8.1(0.5)^{\mathrm{a}}$ & $648(60)^{\mathrm{a}}$ & $1050(75)^{\mathrm{a}}$ \\
\hline 2 & $\mathrm{C}+\mathrm{N}$ & $523(37)^{\mathrm{b}}$ & $15.7(2.7)^{\mathrm{a}}$ & $124(12)^{\mathrm{a}}$ & $7.5(0.8)^{\mathrm{a}, \mathrm{b}}$ & $10.2(0.6)^{b}$ & $467(58)^{\mathrm{a}}$ & $841(75)^{\mathrm{a}, \mathrm{b}}$ \\
\hline $\begin{array}{l}\text { Significant } \\
\text { effects }\end{array}$ & & $\mathrm{T}$ & $T, E, T^{*} E$ & $T, E$ & $T, E, T^{*} E$ & $T, E$ & $T$ & $E, T^{*} E$ \\
\hline
\end{tabular}

a, b, c Within an experiment, treatments that share a letter are not significantly different.

exoenzyme $\mathrm{C}: \mathrm{N}$ only influenced $\mathrm{N}$ mineralization (Fig. 2d, $\mathrm{h}, 1, \mathrm{p})$.

In the sensitivity analysis of kinetic and stoichiometric model parameters, we found that the rate of exoenzyme loss $\left(K_{1}\right)$ as well as the size and $\mathrm{C}: \mathrm{N}$ ratio of the exudate pulse had the greatest effects on the quantity of $\mathrm{N}$ mineralized following an exudate pulse (Table 1). In particular, exudate pulse size and $\mathrm{C}: \mathrm{N}$ ratio influenced the amount of additional exoenzymes synthesized, whereas the rate of enzyme loss determined how long the extra enzymes were active. When all possible combinations of parameter sets were varied (i.e., all values in Table 1), $\mathrm{N}$ mineralization following an exudate pulse increased as the quantity of $\mathrm{N}$-exudation increased (Fig. 3). This relationship was above $1: 1$ for most model parameter sets, indicating a net increase in $\mathrm{N}$ supply for plant roots; the depolymerization and subsequent mineralization of $\mathrm{N}$ exceeded the $\mathrm{N}$ lost from the plant in the exudate pulse.

Taken together, the theoretical model supported the hypothesis. Modeled exudation stimulated microbial biomass, exoenzyme activity, and microbial respiration, but the effects of exudation were stronger when the exudates contained $\mathrm{N}$ as well as $\mathrm{C}$. The exuded $\mathrm{N}$ allowed for the synthesis of additional microbial biomass and exoenzymes, which have low $\mathrm{C}: \mathrm{N}$ ratios and thus high $\mathrm{N}$ requirements.

\subsection{Field experiments}

Microbial biomass responded consistently to exudation treatments across the two experiments (Fig. 4a). Treatment with water or $\mathrm{C}$ alone had no significant effect on microbial biomass relative to the disturbance controls (ANOVA, $p>0.1$, while treatment with $\mathrm{C}$ and $\mathrm{N}$ exudate mimics significantly increased microbial biomass in both experiments (ANOVA, $p<0.05$ ). This effect was consistent re-
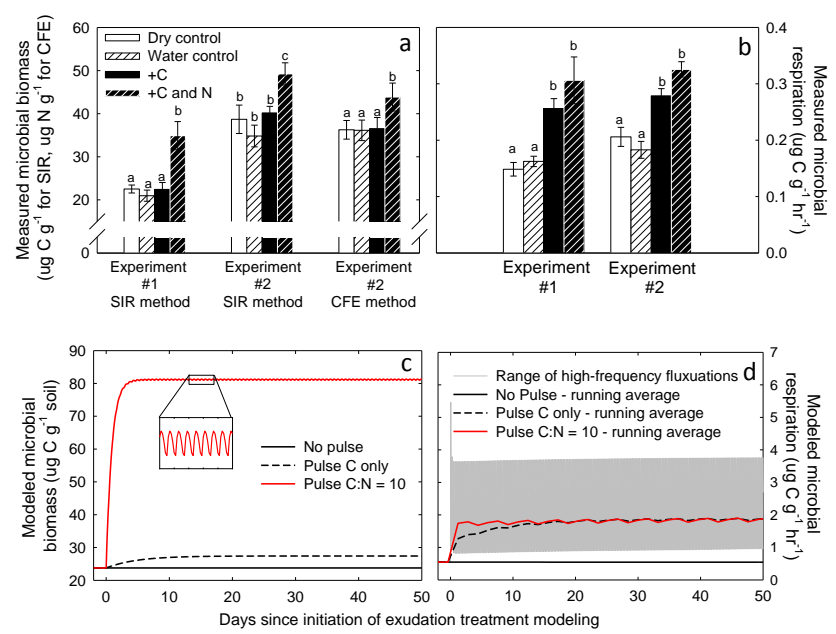

Fig. 4. The response of microbial biomass and respiration to exudation treatments in two field experiments and a theoretical model. Microbial biomass and respiration in the field experiments (a and $\mathbf{b}$ ) were measured after 50 days of treatment, and 50-day model runs were produced for comparison (c and d). Both field experiments consisted of a dry disturbance control, a water control, and treatments with $\mathrm{C}$-only and $\mathrm{C}$ and $\mathrm{N}$ exudate mimics $(n=10)$. Model simulations match the experimental treatments, but the water control was excluded. Treatments that do not share a letter were significantly different $(p<0.05)$. High-frequency fluctuations in the model simulations related to exudation events are shown with an inset (c) and grey lines (d).

gardless of the method employed to measure microbial biomass (i.e., SIR vs. CFE, Fig. 4a). These experimental results agree qualitatively with decomposition model simulations designed to match the experimental methods; microbial 
biomass responded little when these exudate pulses contained $\mathrm{C}$ only, while microbial biomass increased when the exudates also contained N (Fig. 4c).

Microbial respiration measured at the end of each field experiment was significantly increased by the addition of $\mathrm{C}$-only and $\mathrm{C}+\mathrm{N}$ exudate mimics relative to either the disturbance or water controls (Fig. 4b, ANOVA, $p<0.01$ ). These field results were consistent with the model, which predicted an increase in microbial respiration following an exudate pulse, with no effect of exudate $\mathrm{C}: \mathrm{N}$ on the magnitude of the increase (running averages, red and black lines in Fig. 4d). Modeled respiration exhibited high-frequency fluctuations (grey lines in Fig. 4d), as exudate pulses stimulated respiration in the short-term.

In general, the activity of soil exoenzymes was affected by the addition of $\mathrm{C}$ and $\mathrm{N}$ together, while the water and C-only treatments had little effect (Table 2, Fig. 5). In response to the addition of $\mathrm{C}$ and $\mathrm{N}$, there was a significant increase in the activity of hydrolytic enzymes that decompose low molecular weight substrates and a significant decline in the activity of oxidative enzymes that decompose high molecular weight substrates such as lignin (Fig. 5). Overall, the water and Conly exudate mimics did not significantly affect enzyme activities (Fig. 5). There were some exceptions on an enzyme by enzyme basis: C-only exudates increased NAG activity in the first experiment, while the water addition increased NAG and proteolytic enzyme activities in the second experiment (Table 2). The addition of water or $\mathrm{C}$ alone had no effect on the pool of extractable amino acids in the soil (ANOVA, $p>0.1$ ), while the exudation of $\mathrm{C}$ and $\mathrm{N}$ together significantly increased the concentration of amino acids relative to the other treatments (ANOVA, $p<0.05$, Table 2).

\section{Discussion}

The model and field experiments show that the microbial responses to exudate mimics were constrained by $\mathrm{N}$ supply. Experimental delivery of exudate mimics containing $\mathrm{C}$ alone was not sufficient to stimulate microbial and exoenzyme activity in rhizosphere soils. The simultaneous addition of $\mathrm{C}$ and $\mathrm{N}$ in exudate mimics was, however, sufficient to stimulate the growth of microbial biomass, increase microbial respiration, and increase the activity of exoenzymes that decompose low molecular weight $C$ sources (Figs. 4-5). The modeling results suggested that exuding small amounts of $\mathrm{N}$ may be a viable strategy for plant $\mathrm{N}$ acquisition, as the $\mathrm{N}$ mineralized from additional SOM decomposition (i.e., primed $\mathrm{N}$ release) generally exceeded the amount of $\mathrm{N}$ exuded (Fig. 3). Taken together, these modeling and experimental results are consistent with the hypothesis that the ability of soil microbes to utilize root exudates for growth and metabolism is constrained by $\mathrm{N}$ availability. By specifically isolating the effects of $\mathrm{C}$ vs. that of $\mathrm{C}$ and $\mathrm{N}$, this study clearly demon-

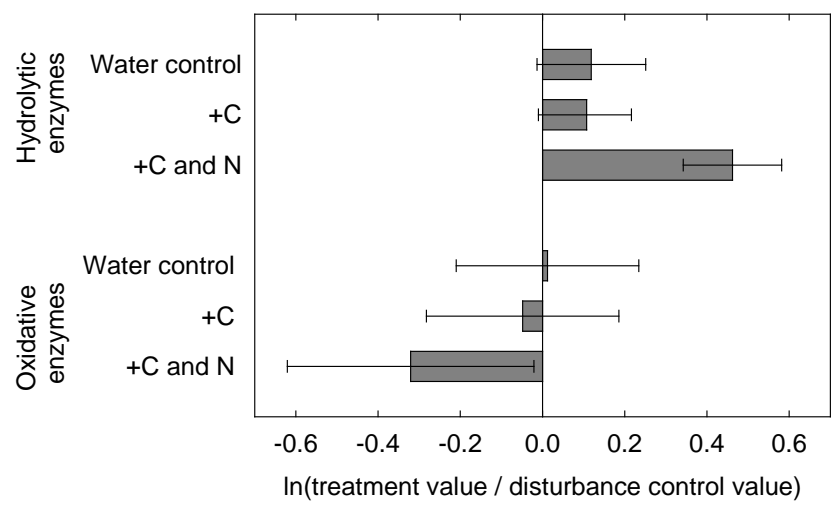

Fig. 5. Meta-analytic summary of the response of soil exoenzyme activity to the delivery of exudate mimics across two field experiments. Experimental treatments included disturbance controls, water controls, $\mathrm{C}$-only exudate mimics, and $\mathrm{C}+\mathrm{N}$ exudate mimics. The response ratio of experimental treatments relative to disturbance controls is shown. Error bars reflect bias-corrected bootstrapped $95 \%$ confidence intervals. Exoenzymes were grouped into categories of hydrolytic enzymes that catalyze the decomposition of low molecular weight substrates (i.e. AP, NAG, BG, and proteolytic enzymes) and oxidative enzymes that catalyze the decomposition of high molecular weight substrates (e.g. the lignolytic enzymes PhenOx and PerOx).

strates that exudate stoichiometry is an important driver of microbial activity in rhizosphere soils.

The model and field data indicate that rhizosphere effects are stronger when the exuded compounds meet microbial demands for multiple elements simultaneously. This conclusion is consistent with data from a variety of biomes where experimental additions of $\mathrm{C}$ - and $\mathrm{N}$-containing substrates stimulated microbial activity in lab and field conditions to a greater degree than C-only additions (Vance and Chapin, 2001; Sorensen et al., 2008; Brown et al., 2009; Currey et al., 2010; Krashevska et al., 2010; Lavoie et al., 2011; but see Yamasaki et al., 2011). The environmental context of nutrient availability, however, may influence the consequences of substrate additions for microbial activity. Fontaine et al. (2011) found that priming of SOM decomposition was strong when cellulose was added to soils of low to moderately high ambient $\mathrm{N}$ availability (grassland soil with a $\mathrm{C}: \mathrm{N}$ ratio of 9.5), but not at high $\mathrm{N}$ availability (i.e., following $\mathrm{N}$ fertilizer application). This suggests that root exudates may stimulate SOM priming most strongly below a threshold of $\mathrm{N}$ availability (Fontaine et al., 2003; Kuzyakov et al., 2000; Hamer and Marschner, 2005), although it seems likely that this threshold varies by ecosystem type, SOM chemistry and/or the amount of root exudation into the rhizosphere.

Exudate effects on soil microbial function are consistent with in situ observations of accelerated rates of biogeochemical fluxes in rhizosphere soil relative to bulk soil in temperate forests. At the Harvard Forest, Brzostek and Finzi (2011) found that the presence of tree roots stimulated microbial and 
exoenzyme activity relative to soils containing only ectomycorrhizal fungal hyphae, suggesting that tree roots themselves have a strong effect on microbial function. The delivery of exudate mimics in this study recreated the observed stimulation of microbial activity by roots in actual rhizosphere soils of temperate forests (Phillips and Fahey, 2005, 2006; Turpault et al., 2007; Phillips et al., 2011), suggesting that exudation can explain much of the observed acceleration of microbial activity and biogeochemical cycling in rhizosphere soils, although altered microbial community structure or activity can also be important (Fierer et al., 2007; Brant et al., 2006a, b; Doornbos et al., 2012).

This study shows that $\mathrm{N}$-compounds in root exudates can affect rhizosphere processes by providing substrates for the synthesis of $\mathrm{N}$-rich microbial biomass and exoenzymes. However, there are two opposing viewpoints in the literature regarding the importance of $\mathrm{N}$-containing compounds in root exudates. On the one hand, solution-culture studies find that the rate of amino acid uptake by plant roots is similar to or greater than efflux rates (Jones and Darrah, 1994; Jones et al., 2009), suggesting that roots re-absorb the amino acids they exude and that amino acids may not contribute to the stimulation of microbial activity in the rhizosphere (but see Phillips et al., 2006). On the other hand, it is well established that roots release amino acids to soils (Bowen, 1969; Rovira, 1969; Smith, 1976; Jaeger et al., 1999; Phillips et al., 2006), and in situ analysis of genetically-modified biosensors (reviewed by Cardon and Gage, 2006) demonstrate that bacteria acquire and use tryptophan in grass rhizospheres (Jaeger et al., 1999), as well as proline and lysine in corn rhizospheres (Vilchez et al., 2000; Espinosa-Urgel and Ramos, 2001), but not in bulk soils. This indicates that microbes acquire at least some of the amino acids exuded from roots into soils, possibly because physicochemical reactions in soils make amino acids subject to a broader array of fates relative to solution culture. In addition to exudation, root turnover and cell sloughing input a substantial quantity of $\mathrm{N}$ to soil, resulting in a "rhizodeposition" flux of $\mathrm{N}$ on the order of $\sim 10 \%$ of total plant N (reviewed by Jones et al., 2009). Thus, roots release $\mathrm{N}$ to soils in a variety of forms; this study suggests that this alleviates microbial N-limitation and thus allows microbes to use the $\mathrm{C}$ in exudates for the synthesis of additional biomass and exoenzymes.

We did not include a treatment where $\mathrm{N}$ was added in the absence of $\mathrm{C}$ and thus cannot definitively exclude a potential effect of $\mathrm{N}$ alone on the observed responses (Figs. 4-5). Our results do not, however, suggest a direct, positive effect of $\mathrm{N}$ on microbial activity. There is a large body of literature indicating that large surface additions of inorganic $\mathrm{N}$ to temperate forests reduces microbial biomass, soil respiration, exoenzyme activities, and decomposition rates, leading to the accumulation of SOM, particularly in the organic horizon (Wallenstein et al., 2006; Treseder, 2008; Janssens et al., 2010; Thomas et al., 2012; but see Saiya-Cork et al., 2002). We observed declines in the activity of exoenzymes targeting high molecular weight forms of SOM in the $\mathrm{C}$ plus $\mathrm{N}$ treatment (Fig. 5), consistent with this literature of direct $\mathrm{N}$ effects. However, we observed increases in microbial biomass, respiration, and the activity of exoenzymes that target low molecular weight substrates in response to the $\mathrm{C}$ and $\mathrm{N}$ treatment; these data are not consistent with previously reported, direct effects of $\mathrm{N}$ addition on microbial and exoenzyme activity. Thus, we suggest that the observed data are not consistent with a direct $\mathrm{N}$ fertilization effect. Rather, we suggest that the microbial response to $\mathrm{C}$ additions alone was constrained by $\mathrm{N}$ availability; adding $\mathrm{N}$ alleviated this constraint and enabled the microbes to utilize the $\mathrm{C}$ exudate mimics for the synthesis of additional biomass and exoenzymes. This interpretation is broadly consistent with the literature specifically studying $\mathrm{C}$ vs. $\mathrm{N}$ limitation of microbial activity, which report stronger effects of $\mathrm{C}$ plus $\mathrm{N}$ than of $\mathrm{N}$ alone (Vance and Chapin, 2001; Sorensen et al., 2008; Brown et al., 2009; Currey et al., 2010; Krashevska et al., 2010).

Modeled microbial biomass was more responsive to $\mathrm{N}$ in exudates than was measured in the field experiments (Fig. 4a vs. 4c). This likely occurred because the model does not include the complexity of real soil communities, which are characterized by multiple functional groups of microorganisms and feedbacks on microbial biomass from higher trophic levels. Predators of rhizosphere microbes, particularly protozoa, can influence $\mathrm{C}$ and $\mathrm{N}$ cycling in the rhizosphere with concomitant effects on root-N availability (Griffiths, 1990; Zwart et al., 1994; Bonkowski, 2004; Cardon and Gage, 2006). We did not study these multi-trophic interactions, but this would be an interesting area for future research.

The responses of individual enzymes to exudate mimics were largely consistent from a stoichiometric perspective, although the results of the second experiment were more variable. In the first experiment, the release of exudate mimics containing only $\mathrm{C}$ stimulated the activity of an enzyme that decomposes N-containing substrates (NAG), while the exudate mimics containing $\mathrm{C}$ and $\mathrm{N}$ stimulated the activity of $\mathrm{P}$ releasing enzymes (AP) and increased soil $\mathrm{N}$ availability (extractable amino acids increased by $130 \%$ relative to water or dry controls, Table 2). Thus, the first experiment suggested that $\mathrm{C}$ addition exacerbated microbial-N limitation, while $\mathrm{C}$ and $\mathrm{N}$ addition induced microbial-P limitation. In the second experiment, AP and amino-acid pools responded as in the first experiment, whereas water addition alone significantly increased NAG activity relative to all other treatments (Table 2). The same result was obtained when the samples were re-analyzed (data not shown), so this is not likely the result of a procedural error. It is possible that recovery from drought conditions preceding the time of soil sampling for the second experiment increased substrate supply across all treatments (Fig. B1), such that the exudate additions had a smaller relative effect on overall soil substrate availabilities. Alternatively, the strong water effect may have simply been a sampling effect associated with the high spatial variability 
characteristic of soils. In general, the responses of individual enzymes across these experiments were stoichiometrically consistent and reflected inducible exoenzyme production in response to nutrient supply and demand (Koch, 1985; Allison and Vitousek, 2005).

The differential response of enzymes targeting low vs. high molecular weight SOM to treatment with exudate mimics (Fig. 5) suggest that the exudation of low molecular weight substrates from plant roots may increase the rate at which low molecular weight SOM is decomposed, while reducing the decomposition rate of other types of SOM. This result is generally consistent with the theory that soil microbes constitutively produce exoenzymes at some low level that allows the microbes to detect environmental levels of insoluble polymers (e.g., cellulose) by the rate of monomer supply (e.g., glucose uptake into microbial cells); this allows for the inducible production of additional exoenzymes targeting the insoluble polymer (Koch, 1985; Chróst, 1991; Koroljova-Skorobogatko et al., 1998; Shackle et al., 2000; Allison and Vitousek, 2005). Under this framework, root exudation of monomers (e.g., glucose) would largely stimulate the decomposition of relatively low molecular weight SOM (e.g., cellulose). It is also possible that increased C supply from exudation leads to a change in microbial community composition, particularly favoring $r$-selected copiotrophic microbes with limited oxidative enzyme production at the expense of K-selected oligotrophic microbes that presumably have greater enzymatic diversity to decompose complex SOM such as lignin (Fontaine et al., 2003, 2011; Fierer et al., 2007; Guenet et al., 2010). We have no data to address microbial community change in the current study, but $\mathrm{C}$ additions to temperate forest soils have been shown to increase the relative abundance of copiotrophic Bacteroidetes and $\beta$-Proteobacteria (Fierer et al., 2007). Finally, we speculate that root exudation primarily affects the decomposition of relatively low molecular weight SOM pools, but that plants are likely capable of stimulating the decomposition of high molecular weight SOM pools (e.g., lignin) through other mechanisms such as $\mathrm{C}$ allocation to mycorrhizal fungal associates, which decompose a wide range of SOM substrates and transfer large quantities of nutrients to plant hosts (Chalot and Brun, 1998; Hodge et al., 2001; Hobbie and Hobbie, 2006; Talbot et al., 2008; Kaiser et al., 2011; Pritsch and Garbaye, 2011).

\section{Conclusions}

Analysis of a theoretical model of decomposition and two field experiments show that the simultaneous exudation of $\mathrm{C}$ and $\mathrm{N}$ elicits a larger microbial and enzymatic response in the rhizosphere than the exudation of $\mathrm{C}$ alone. This suggests that plants can influence microbial activity and nutrient availability in the rhizosphere through the exudation of compounds that simultaneously meet microbial demands for multiple elements. Our analyses support the idea that exudation of $\mathrm{C}+\mathrm{N}$ was sufficient to recreate known rhizosphere effects (e.g., higher rates of microbial biomass, respiration, and exoenzyme activities), highlighting the importance of root exudation to belowground ecology. This study suggests that exudate stoichiometry is an important and underappreciated driver of soil microbial activity.

\section{Appendix A}

\section{Model description}

The model of decomposition used in this study was based on the published equations of Schimel and Weintraub (2003), modified using some equations from Allison et al. (2010). Here, we defined all of the model equations and parameters. Model parameters, pools, and fluxes were defined in Tables A1-A3.

We made four modifications to the model of Schimel and Weintraub (2003). (1) The original model assumed microbes instantaneously took up all available dissolved nutrients (i.e. DOC and DON). While this approach may be suitable for modeling steady-state conditions, it does not accurately reflect time lags regarding the effect of substrate supply on microbial activity. Thus, we modeled microbial DOC and DON uptake using Michaelis-Menten kinetics as in Allison et al. (2010). (2) The equation governing inorganic-N immobilization (Eq. 18 in Schimel and Weintraub, 2003) was reversed in the original publication; microbes could immobilize $\mathrm{N}$ under $\mathrm{C}$-limitation, but immobilization of $\mathrm{N}$ was not permitted when microbes were $\mathrm{N}$-limited. We corrected this by reversing the equation so that microbes could take up inorganic $\mathrm{N}$ when in an $\mathrm{N}$-limited state. (3) The Schimel and Weintraub (2003) model did not include inorganic-N sinks, and as a consequence the pool of inorganic $\mathrm{N}$ grew without bound as the model was run forward. By allowing microbial$\mathrm{N}$ immobilization under N-limited conditions (change 2, above) the lack of inorganic- $\mathrm{N}$ losses gave microbes access to a virtually unlimited supply of inorganic $\mathrm{N}$, which is not realistic. Inorganic $\mathrm{N}$ is removed from soils relatively quickly (Berntson and Aber, 2000; Robertson and Groffman, 2007) through root-uptake (Perakis and Hedin, 2001), leaching (Vitousek and Melillo, 1979; Lovett et al., 2002), abiotic interactions with soil minerals (Davidson et al., 2003), denitrification (Potter et al., 1996; Seitzinger et al., 2006), $\mathrm{NH}_{3}$ volatilization (Schlesinger and Peterjohn, 1991; Bouwman et al., 1997), as well as microbial uptake (Zak et al., 1990; Davidson et al., 1992). Combinations of these mechanisms operate at varying temporal scales in undisturbed forests (e.g., Perakis and Hedin, 2001). To avoid the complexity of adding these processes to the model, we modeled inorganic-N loss as a simple first-order kinetic process by assuming that $40 \%$ of the inorganic-N pool was lost at each time step. This modification reduced the equilibrium value 
Table A1. Model parameters. List of parameter abbreviations, typical values, and definitions.

\begin{tabular}{|c|c|c|}
\hline$K_{\text {ep }}$ & 0.0005 & Rate of enzyme production per unit microbial biomass (unit-less) \\
\hline$K_{1}$ & 0.05 & Enzyme decay constant (unit-less) \\
\hline$K_{\mathrm{m}}$ & 0.01 & Microbial maintenance rate, includes cost of maintaining living cells and biomass turnover (unit-less) \\
\hline SUE & 0.5 & Substrate use efficiency: the fraction of DOC uptake that is converted to biomass or enzymes (unit-less) \\
\hline$K_{\mathrm{t}}$ & 0.012 & Proportion of microbial biomass that dies each time step (unit-less) \\
\hline$K_{\mathrm{r}}$ & 0.85 & $\begin{array}{l}\text { Proportion of dead microbial biomass that is recycled to DOC and DON pools (unit-less). } \\
\text { The remainder re-enters SOC and SON pools. }\end{array}$ \\
\hline Pulse $_{\mathrm{C}}$ & 50 & Size of exudate pulse ( $\left.\mathrm{ug} \mathrm{Cg}^{-1}\right)$ \\
\hline $\mathrm{CN}_{\mathrm{s}}$ & 20 & $\mathrm{C}: \mathrm{N}$ ratio of the soil (SOC/SON) \\
\hline $\mathrm{CN}_{\mathrm{m}}$ & 7 & $\mathrm{C}: \mathrm{N}$ ratio of the microbes \\
\hline $\mathrm{CN}_{\text {pulse }}$ & 100 & $\mathrm{C}: \mathrm{N}$ ratio of the exudate pulse \\
\hline $\mathrm{CN}_{\mathrm{enz}}$ & 3 & $\mathrm{C}: \mathrm{N}$ ratio of the enzymes \\
\hline Vmaxuptake & $01.5 \times 10^{8}$ & Pre-exponential rate of DOC uptake (ug DOC $\mathrm{g}^{-1} \mathrm{~h}^{-1}$ ) \\
\hline Eauptake & 47 & Activation energy of DOC uptake $\left(\mathrm{kJ} \mathrm{mol}^{-1}\right.$ degree $\left.\mathrm{C}^{-1}\right)$ \\
\hline Gasconst & 0.008314 & Universal gas constant $\left(\mathrm{kJ} \mathrm{mol}^{-1} \mathrm{~K}^{-1}\right)$ \\
\hline Kmuptakeslope & 0.015 & Rate by which the $k_{\mathrm{m}}$ of DOC uptake increases with each increase in temperature (ug DOC g ${ }^{-1}{ }^{\circ} \mathrm{C}^{-1}$ ) \\
\hline Kmuptake0 & 0.154 & $K_{\mathrm{m}}$ of DOC uptake at $0^{\circ} \mathrm{C}\left(\mathrm{ug}\right.$ DOC $\left.\mathrm{g}^{-1}\right)$ \\
\hline$K_{\mathrm{es}}$ & 0.3 & $\begin{array}{l}\text { Michaelis-Menten half-saturation constant; enzyme pool size value at which the decomposition } \\
\text { of SOC/SON is half-saturated }\end{array}$ \\
\hline kappa $_{D}$ & 1.0 & Decomposition constant for SOC/SON pool \\
\hline
\end{tabular}

Table A2. Model Pools.

\begin{tabular}{ll}
\hline BC & Microbial biomass C \\
BN & Microbial biomass N \\
EC & Enzyme C \\
EN & Enzyme N \\
N0 & Mineral N \\
DOC & Dissolved organic C \\
DON & Dissolved organic N \\
\hline
\end{tabular}

for the inorganic- $\mathrm{N}$ pool from infinity to $\sim 3.5 \mu \mathrm{g} \mathrm{N}$ g soil ${ }^{-1}$ using the default parameter values (Table 1), which corresponds well with measurements of inorganic $\mathrm{N}$ in the temperate forest soils used for the field experiments $(3.7 \pm$ standard deviation of $1.6 \mu \mathrm{g} \mathrm{Ng}$ soil $^{-1}$, JE Drake unpublished data; Brzostek and Finzi 2011). This change gave microbes access to a realistic pool of mineral N. (4) Schimel and Weintraub (2003) modeled enzyme production to be a constant fraction of microbial DOC uptake. When multiple exudate pulses were added to a model using this formulation, microbes went extinct (i.e., microbial biomass $\mathrm{C}$ and $\mathrm{N}$ became negative) because microbes were "forced" to produce large amounts of enzymes at the expense of their own biomass. To avoid this unrealistic scenario, we modeled the rate of enzyme production to be directly proportional to microbial biomass as in Allison et al. (2010).

\section{A1 Decomposition of soil organic C and N (SOC and SON)}

Insoluble soil organic C and N (SOC and SON) were assumed to be present in saturating amounts at the microbial
Table A3. Model Fluxes.

\begin{tabular}{|c|c|}
\hline Dc & $\begin{array}{l}\text { Rate of conversion from SOC to } \\
\text { DOC (decomposition) }\end{array}$ \\
\hline Dn & $\begin{array}{l}\text { Rate of conversion from SON to } \\
\text { DON (decomposition) }\end{array}$ \\
\hline Uc & Rate of microbial DOC uptake \\
\hline Un & Rate of microbial DON uptake \\
\hline $\mathrm{EP}_{\mathrm{c}}$ & Rate of enzyme $\mathrm{C}$ production \\
\hline $\mathrm{EP}_{\mathrm{n}}$ & Rate of enzyme $\mathrm{N}$ production \\
\hline $\mathrm{EL}_{\mathrm{c}}$ & Rate of enzyme $\mathrm{C}$ decay \\
\hline $\mathrm{EL}_{\mathrm{n}}$ & Rate of enzyme $\mathrm{N}$ decay \\
\hline$R_{\mathrm{m}}$ & Maintenance respiration rate \\
\hline$R_{\mathrm{e}}$ & Respiration to support the production of enzymes \\
\hline$R_{\mathrm{g}}$ & Respiration to support growth of microbial biomass \\
\hline$R_{\mathrm{O}}$ & $\begin{array}{l}\text { Overflow respiration, when DOC is taken up in } \\
\text { excess of microbial demand }\end{array}$ \\
\hline$J_{\mathrm{n}}$ & Microbial immobilization of inorganic $\mathrm{N}$ \\
\hline$M_{\mathrm{n}}$ & Rate of microbial N mineralization \\
\hline $\mathrm{CY}_{\mathrm{c}}$ & Recycling of dead microbial C back to DOC \\
\hline$H_{\mathrm{c}}$ & Loss of dead microbial C to SOC \\
\hline $\mathrm{CY}_{\mathrm{n}}$ & Recycling of dead microbial $\mathrm{N}$ back to DON \\
\hline$H_{\mathrm{n}}$ & Loss of dead microbial $\mathrm{N}$ to $\mathrm{SON}$ \\
\hline
\end{tabular}

scale as in Schimel and Weintraub (2003). The rate of depolymerization of SOC and SON into soluble forms of dissolved organic C and N (DOC and DON) was assumed to follow Michaelis-Menten dynamics related to the quantity of soil enzymes. SOC and SON depolymerization (Dc and $\mathrm{Dn})$ were linked by the soil $\mathrm{C}: \mathrm{N}$ ratio.

$\mathrm{Dc}=\operatorname{kappa}_{\mathrm{D}} \times \frac{\mathrm{EC}}{K_{\mathrm{es}}+\mathrm{EC}}$ 
$\mathrm{Dn}=\mathrm{Dc} / \mathrm{CN}_{\mathrm{s}}$

\section{A2 Microbial uptake of DOC and DON}

As explained in the main text, we modified the approach of Schimel and Weintraub (2003) to model microbial uptake of DOC and DON as in Allison et al. (2010). First, the maximum velocity $\left(V_{\max }\right)$ and half-saturation constant $\left(K_{\mathrm{m}}\right)$ were calculated from soil temperature $(T)$, which was set at a constant $20^{\circ} \mathrm{C}$ for all of the modeling.

Vmaxuptake $=$ Vmaxuptake

$$
\cdot e^{-1 \cdot(\text { Eauptake } \div \text { gasconst } \cdot(T+273.15))}
$$

Kmuptake $=$ Kmuptakeslope $\cdot T+$ Kmuptake

Next, the rates of DOC and DON uptake were calculated:

$\mathrm{Uc}=$ Vmaxuptake $\times \mathrm{BC} \times \mathrm{DOC} \div($ Kmuptake $+\mathrm{DOC})$

$\mathrm{Un}=$ Vmaxuptake $\times \mathrm{BN} \times \mathrm{DON} \div($ Kmuptake $+\mathrm{DON})$

Rates of uptake were bounded by available substrate: i.e., Uc could not exceed DOC supply, and Un could not exceed DON supply.

\section{A3 Microbial physiology}

In the model, microbes used organic $\mathrm{C}$ and $\mathrm{N}$ resources to synthesize enzymes, produce more biomass, and to meet respiration requirements. Some aspects of physiology depended on whether microbes were limited by $\mathrm{C}$ or $\mathrm{N}$ resources. At each time step, if the uptake of DOC was not sufficient to meet microbial demand, the microbes were considered C-limited. Conversely, if DOC uptake exceeded microbial demand, the microbes were considered $\mathrm{N}$-limited.

$\mathrm{IF} \mathrm{Uc}<R_{\mathrm{m}}+\frac{\mathrm{EP}_{\mathrm{c}}}{\mathrm{SUE}}+\left(\mathrm{Un}-\mathrm{EP}_{\mathrm{n}}\right) \times \frac{\mathrm{CN}_{\mathrm{m}}}{\mathrm{SUE}}$,

then C-limitation.

$\mathrm{IF} \mathrm{Uc} \geq R_{\mathrm{m}}+\frac{\mathrm{EP}_{\mathrm{c}}}{\mathrm{SUE}}+\left(U n-\mathrm{EP}_{\mathrm{n}}\right) \times \frac{\mathrm{CN}_{\mathrm{m}}}{\mathrm{SUE}}$,

then $\mathrm{N}$-limitation.

The rate of enzyme production was directly proportional to microbial biomass, and enzymes decayed in a first-order process, as in Allison et al. (2010).

$\mathrm{EP}_{\mathrm{c}}=K_{\text {ep }} \times \mathrm{BC}$

$\mathrm{EL}_{\mathrm{c}}=K_{1} \times \mathrm{EC}$
The $\mathrm{N}$ transferred during enzyme production and loss were linked to Eqs. (A8) and (A9) by the enzyme $\mathrm{C}: \mathrm{N}$ ratio.

$\mathrm{EP}_{\mathrm{n}}=\mathrm{EP}_{\mathrm{c}} \div \mathrm{CN}_{\mathrm{enz}}$

$\mathrm{EL}_{\mathrm{n}}=\mathrm{EL}_{\mathrm{c}} \div \mathrm{CN}_{\mathrm{enz}}$

Microbes utilized organic $\mathrm{C}$ to support respiration processes, such as maintenance, enzyme production, growth, and overflow metabolism (when in an N-limited state).

$R_{\mathrm{m}}=K_{\mathrm{m}} \times \mathrm{BC}$

$R_{\mathrm{e}}=\mathrm{EP}_{\mathrm{c}} \times(1-\mathrm{SUE}) / \mathrm{SUE}$

IF C-limited $R_{\mathrm{g}}=\left(\mathrm{Uc}-\frac{\mathrm{EP}_{\mathrm{c}}}{\mathrm{SUE}}-R_{\mathrm{m}}\right) \times(1-\mathrm{SUE})$

IF N-limited $R_{\mathrm{g}}=\left(\mathrm{Un}+J_{\mathrm{n}}-\mathrm{EP}_{\mathrm{n}}\right) \times \mathrm{CN}_{\mathrm{m}}$

$\times(1-\mathrm{SUE}) / \mathrm{SUE}$

IF C-limited $R_{\mathrm{O}}=0$

IF N-limited $R_{\mathrm{O}}=\left(\mathrm{Uc}-R_{\mathrm{m}}-\frac{\mathrm{EP}_{\mathrm{c}}}{\mathrm{SUE}}\right)$

$$
-\left(\mathrm{Un}+J_{\mathrm{n}}-\mathrm{EP}_{\mathrm{n}}\right) \times \frac{\mathrm{CN}_{\mathrm{m}}}{\mathrm{SUE}}
$$

The rate of microbial uptake of inorganic $\mathrm{N}$ (immobilization) was zero under C-limitation. However, immobilization occurred during N-limitation:

IF N-limited $J_{\mathrm{n}}=\left(\mathrm{Uc}-R_{\mathrm{m}}-\frac{\mathrm{EP}_{\mathrm{c}}}{\mathrm{SUE}}\right) \times \frac{\mathrm{SUE}}{\mathrm{CN}_{\mathrm{m}}}-\mathrm{EP}_{\mathrm{n}}-\mathrm{Un}$

Microbes mineralized $\mathrm{N}$ when limited by $\mathrm{C}$ resources, but $\mathrm{N}$ mineralization was zero under $\mathrm{N}$-limitation.

IF C-limited $M_{\mathrm{n}}=\mathrm{Un}-\mathrm{EP}_{\mathrm{n}}-\left(\mathrm{Uc}-R_{\mathrm{m}}-\frac{\mathrm{EP}_{\mathrm{c}}}{\mathrm{SUE}}\right) \times \frac{\mathrm{SUE}}{\mathrm{CN}_{\mathrm{m}}}$

\section{A4 Recycling of dead microbial biomass and enzymes}

As in Schimel and Weintraub (2003) and Allison et al. (2010), we assumed that a fixed proportion $\left(K_{\mathrm{r}}\right)$ of the $\mathrm{C}$ and $\mathrm{N}$ contained in dead microbial biomass was returned to soluble (DOC and DON) pools, with the remainder returned to insoluble pools (SOC and SON).

$\mathrm{CY}_{\mathrm{c}}=K_{\mathrm{t}} \times K_{\mathrm{r}} \times \mathrm{BC}$

$\mathrm{CY}_{\mathrm{n}}=\mathrm{CY}_{\mathrm{c}} \div \mathrm{CN}_{\mathrm{m}}$

$H_{\mathrm{c}}=K_{\mathrm{t}} \times\left(1-K_{\mathrm{r}}\right) \times \mathrm{BC}$

$H_{\mathrm{n}}=H_{\mathrm{c}} \div \mathrm{CN}_{\mathrm{m}}$ 


\section{A5 Changes in Pool Size}

After calculating the fluxes above, the model calculated the pool sizes at the next time step (i.e. at time step $i+1$ ).

$$
\begin{aligned}
\mathrm{BC}(i+1)= & \mathrm{BC}(i)+\mathrm{Uc}-\mathrm{CY}_{\mathrm{c}}-\mathrm{EP}_{\mathrm{c}} \\
& -R_{\mathrm{o}}-H_{\mathrm{c}}-R_{\mathrm{e}}-R_{\mathrm{m}}-R_{\mathrm{g}}
\end{aligned}
$$

$\mathrm{BN}(i+1)=\mathrm{BN}(i)+\mathrm{Un}-\mathrm{CY}_{\mathrm{n}}-\mathrm{EP}_{\mathrm{n}}-M_{\mathrm{n}}+J_{\mathrm{n}}-H_{\mathrm{n}}$

$\mathrm{EC}(i+1)=\mathrm{EC}(i)+\mathrm{EP}_{\mathrm{c}}-\mathrm{EL}_{\mathrm{c}}$

$\mathrm{EN}(i+1)=\mathrm{EN}(i)+\mathrm{EP}_{\mathrm{n}}-\mathrm{EL}_{\mathrm{n}}$

$\mathrm{DOC}(i+1)=\mathrm{DOC}(i)+\mathrm{Dc}-\mathrm{Uc}+\mathrm{CY}_{\mathrm{c}}$

$\mathrm{DON}(i+1)=\mathrm{DON}(i)+\mathrm{Dn}-\mathrm{Un}+\mathrm{CY}_{\mathrm{n}}$

During an exudation event, the quantity Pulse_C was also added to the DOC pool, and Pulse $\mathrm{C}_{\mathrm{C}} / \mathrm{CN}_{\text {pulse }}$ was added to the DON pool.

As explained in the main text, we assumed that $40 \%$ of the mineral $\mathrm{N}$ pool was lost to the aggregate activity of many un-modeled fluxes (e.g. leaching, plant uptake, volatilization, and immobilization with soil minerals).

$\mathrm{N} 0(i+1)=0.6 \times \mathrm{N} 0(i)+M_{\mathrm{n}}-J_{\mathrm{n}}$

\section{Appendix B}

\section{Environmental conditions during the field experiments}

We measured soil temperature at 5-cm depth (type-T thermocouple ) and soil moisture at 4.5-cm depth (time-domain reflectometry probes, model CS615, Campbell Scientific, Logan, Utah, USA) as described previously (Savage et al., 2009). The nearby Environmental Measurement Site has measured whole-ecosystem exchange of $\mathrm{CO}_{2}$ and $\mathrm{H}_{2} \mathrm{O}$ since 1991 (EMS, Urbanski et al., 2007); these data were downloaded from the Harvard Forest data archive (Munger and Wofsy, 1999) and used as a reference to time the exudation experiments during seasonal periods that typically have high rates of ecosystem $\mathrm{C}$ uptake.

We performed two 50-day exudate addition experiments during the summer of 2011. The first experiment was performed during early- to mid-summer, a period characterized by increasing soil temperatures, decreasing soil water content (Fig. B1a), and high rates of net ecosystem C uptake (Fig. B1b). The second experiment was performed in the mid- to late-summer. During this time, soil temperatures declined slightly, and soil moisture increased (Fig. B1a). Net ecosystem $\mathrm{C}$ uptake is typically positive during this time period, although rates of $\mathrm{C}$ uptake are generally lower than the early- to mid-summer (Fig. B1b).
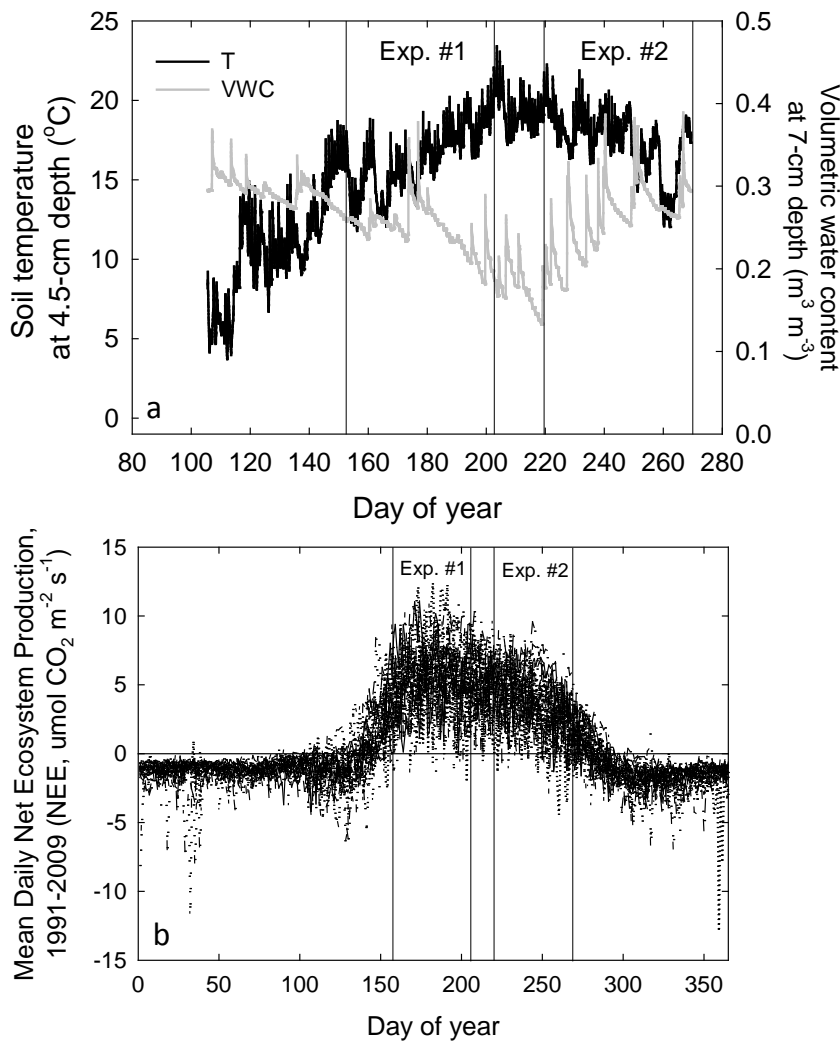

Fig. B1. Environmental attributes during field exudation treatments at Harvard Forest, MA, 2011 (a). There were two experiments (Exp. \#1 and Exp. \#2), demarcated by thin vertical black lines. Both experiments lasted 50 days. Net Ecosystem Exchange (NEE) of $\mathrm{CO}_{2}$ measured at the Environmental Measurements Site (EMS) over the period 1991-2006 showed a consistent seasonal cycle (b).

\section{Supplementary material related to this article is available online at: http://www.biogeosciences.net/10/ 821/2013/bg-10-821-2013-supplement.zip.}

Acknowledgements. We gratefully acknowledge Eric Davidson and Kathleen Savage (Woods Hole Research Center) for their guidance and support during this experiment. Logistical support and site access was provided by Audrey Barker Plotkin and other Harvard Forest staff. We thank Jackie Burmeister, Andrea Martin, and other members of Emily Bernhardt's lab (Duke University) for their work designing the microlysimeter exudate-delivery apparatus. We thank Kim Spiller for her help running lab analyses, and the many Boston University undergraduates who helped process soil samples.

Edited by: M. Bahn 


\section{References}

Ainsworth, E. A. and Long, S. P.: What have we learned from 15 years of free-air $\mathrm{CO}_{2}$ enrichment (FACE)? A meta-analytic review of the responses of photosynthesis, canopy, New Phytol., 165, 351-371, 2005.

Aitkenhead, J. A. and McDowell, W. H.: Soil C : N ratio as a predictor of annual riverine DOC flux at local and global scales, Global Biogeochem. Cy., 14, 127-138, 2000.

Allison, S. D. and Vitousek, P. M.: Responses of extracellular enzymes to simple and complex nutrient inputs, Soil Biol. Biochem., 37, 937-944, 2005.

Allison, S. D., Wallenstein, M. D., and Bradford, M. A.: Soil-carbon response to warming dependent on microbial physiology, Nat. Geosci., 3, 336-340, 2010.

Anderson, J. P. E. and Domsch, K. H.: Physiological method for quantitative measurement of microbial biomass in soils, Soil Biol. Biochem., 10, 215-221, 1978.

Basu, U., Godbold, D., and Taylor, G. J.: Aluminum resistance in Triticum aestivum associated with enhanced exudation of malate, J. Plant. Physiol., 144, 747-753, 1994.

Batjes, N. H.: Total carbon and nitrogen in the soils of the world, Eur. J. Soil. Sci., 47, 151-163, 1996.

Berntson, G. M. and Aber, J. D.: Fast nitrate immobilization in N saturated temperate forest soils, Soil Biol. Biochem., 32, 151156, 2000.

Bertin, C., Yang, X., and Weston, L. A.: The role of root exudates and allelochemicals in the rhizosphere, Plant Soil, 256, 67-83, 2003.

Blagodatsky, S., Blagodatskaya, E., Yuyukina, T., and Kuzyakov, Y.: Model of apparent and real priming effects: Linking microbial activity with soil organic matter decomposition, Soil Biol. Biochem., 42, 1275-1283, 2010.

Blagodatsky, S., Grote, R., Kiese, R., Werner, C., and ButterbachBahl, K.: Modelling of microbial carbon and nitrogen turnover in soil with special emphasis on $\mathrm{N}$-trace gases emission, Plant Soil, 346, 297-330, 2011.

Bonkowski, M.: Protozoa and plant growth: the microbial loop in soil revisited, New Phytol., 162, 617-631, 2004.

Boose, E.: Fisher Meteorological Station (since 2001), Harvard Forest Data Archive, HF001, 2001.

Boose, E. and Gould, E.: Shaler Meteorological Station (19642002), Harvard Forest Data Archive, HF000, 1999.

Borken, W., Davidson, E. A., Savage, K., Gaudinski, J., and Trumbore, S. E.: Drying and wetting effects on carbon dioxide release from organic horizons, Soil Sci. Soc. Am. J., 67, 1888-1896, 2003.

Borken, W., Davidson, E. A., Savage, K., Sundquist, E. T., and Steudler, P.: Effect of summer throughfall exclusion, summer drought, and winter snow cover on methane fluxes in a temperate forest soil, Soil Biol. Biochem., 38, 1388-1395, 2006a.

Borken, W., Savage, K., Davidson, E. A., and Trumbore, S. E.: Effects of experimental drought on soil respiration and radiocarbon efflux from a temperate forest soil, Glob Change Biol., 12, 177193, 2006b.

Bouwman, A. F., Lee, D. S., Asman, W. A. H., Dentener, F. J., VanderHoek, K. W., and Olivier, J. G. J.: A global high-resolution emission inventory for ammonia, Global Biogeochem. Cy., 11, 561-587, 1997.
Bowden, R. D., Newkirk, K. M., and Rullo, G. M.: Carbon dioxide and methane fluxes by a forest soil under laboratory-controlled moisture and temperature conditions, Soil Biol. Biochem., 30, 1591-1597, 1998.

Bowen, G. D.: Nutrient status effects on loss of amides and amino acids from pine roots, Plant Soil, 30, 139-142, 1969.

Brant, J. B., Myrold, D. D., and Sulzman, E. W.: Root controls on soil microbial community structure in forest soils, Oecologia, 148, 650-659, 2006a.

Brant, J. B., Sulzman, E. W., and Myrold, D. D.: Microbial community utilization of added carbon substrates in response to longterm carbon input manipulation, Soil Biol. Biochem., 38, 22192232, $2006 b$.

Brown, A. L. P., Garland, J. L., and Day, F. P.: Physiological Profiling of Soil Microbial Communities in a Florida Scrub-Oak Ecosystem: Spatial Distribution and Nutrient Limitations, Microb. Ecol., 57, 14-24, 2009.

Brzostek, E. R. and Finzi, A. C.: Substrate supply, fine roots, and temperature control proteolytic enzyme activity in temperate forest soils, Ecology, 92, 892-902, 2011

Brzostek, E. R. and A. C. Finzi: Seasonal variation in the temperature sensitivity of proteolytic enzyme activity in temperate forest soils, J. Geophys. Res., 117, G01018, doi:10.1029/2011JG001688, 2012.

Brzostek, E. R., Greco, A., Drake, J. E., and Finzi, A. C.: Root carbon inputs to the rhizosphere stimulate extracellular enzyme activity and increase nitrogen availability in temperate forest soils, Biogeochemistry, doi:10.1007/s10533-012-9818-9, 2012.

Cardon, Z. G. and Gage, D. J.: Resource exchange in the rhizosphere: Molecular tools and the microbial perspective, Annu. Rev. Ecol. Evol. S., 37, 459-488, 2006.

Chalot, M. and Brun, A.: Physiology of organic nitrogen acquisition by ectomycorrhizal fungi and ectomycorrhizas, Fems Microbiol. Rev., 22, 21-44, 1998.

Chróst, R. J.: Environmental control of the synthesis and activity of aquatic microbial ectoenzymes, in: Brock Spr. S., edited by: Chróst, R. J., Springer-Verlag, New York, 29-59, 1991.

Cleveland, C. C. and Liptzin, D. C.: N : P stoichiometry in soil: is there a "Redfield ratio" for the microbial biomass?, Biogeochemistry, 85, 235-252, 2007

Coleman, K., Jenkinson, D. S., Crocker, G. J., Grace, P. R., Klir, J., Korschens, M., Poulton, P. R., and Richter, D. D.: Simulating trends in soil organic carbon in long-term experiments using RothC-26.3, Geoderma, 81, 29-44, 1997.

Currey, P. M., Johnson, D., Sheppard, L. J., Leith, I. D., Toberman, H., van der Wal, R., Dawson, L. A., and Artz, R. R. E.: Turnover of labile and recalcitrant soil carbon differ in response to nitrate and ammonium deposition in an ombrotrophic peatland, Global Change Biol., 16, 2307-2321, 2010.

Dakora, F. D. and Phillips, D. A.: Root exudates as mediators of mineral acquisition in low-nutrient environments, Plant Soil, 245, 35-47, 2002.

Davidson, E. A., Hart, S. C., and Firestone, M. K.: Internal Cycling of Nitrate in Soils of a Mature Coniferous Forest, Ecology, 73, 1148-1156, 1992.

Davidson, E. A., Belk, E., and Boone, R. D.: Soil water content and temperature as independent or confounded factors controlling soil respiration in a temperate mixed hardwood forest, Global Change Biol., 4, 217-227, 1998. 
Davidson, E. A., Chorover, J., and Dail, D. B.: A mechanism of abiotic immobilization of nitrate in forest ecosystems: the ferrous wheel hypothesis, Global Change Biol., 9, 228-236, 2003.

Davidson, E. A., Savage, K. E., Trumbore, S. E., and Borken, W.: Vertical partitioning of $\mathrm{CO}_{2}$ production within a temperate forest soil, Global Change Biol., 12, 944-956, 2006.

De Nobili, M., Contin, M., Mondini, C., and Brookes, P. C.: Soil microbial biomass is triggered into activity by trace amounts of substrate, Soil Biol. Biochem., 33, 1163-1170, 2001.

Dilkes, N. B., Jones, D. L., and Farrar, J.: Temporal Dynamics of Carbon Partitioning and Rhizodeposition in Wheat, Plant Physiol., 134, 706-715, 2004.

Doornbos, R. F., van Loon, L. C., and Bakker, P.: Impact of root exudates and plant defense signaling on bacterial communities in the rhizosphere, A review, Agron. Sustain. Dev., 32, 227-243, 2012.

Drake, J. E., Gallet-Budynek, A., Hofmockel, K. S., Bernhardt, E. S., Billings, S. A., Jackson, R. B., Johnsen, K. S., Lichter, J., McCarthy, H. R., McCormack, M. L., Moore, D. J. P., Oren, R., Palmroth, S., Phillips, R. P., Pippen, J. S., Pritchard, S. G., Treseder, K. K., Schlesinger, W. H., DeLucia, E. H., and Finzi, A. C.: Increases in the flux of carbon belowground stimulate nitrogen uptake and sustain the long-term enhancement of forest productivity under elevated $\mathrm{CO}_{2}$, Ecol. Lett., 14, 349-357, 2011.

Duncan, D. B.: Multiple range and multiple F-tests, Biometrics, 11, $1-42,1955$.

Elser, J. J., Sterner, R. W., Gorokhova, E., Fagan, W. F., Markow, T. A., Cotner, J. B., Harrison, J. F., Hobbie, S. E., Odell, G. M., and Weider, L. J.: Biological stoichiometry from genes to ecosystems, Ecol. Lett., 3, 540-550, 2000.

Espinosa-Urgel, M. and Ramos, J. L.: Expression of a Pseudomonas putida aminotransferase involved in lysine catabolism is induced in the rhizosphere, Appl. Environ. Microbiol., 67, 5219-5224, 2001.

Farrar, J., Hawes, M., Jones, D., and Lindow, S.: How roots control the flux of carbon to the rhizosphere, Ecology, 84, 827-837, 2003.

Fierer, N., Bradford, M. A., and Jackson, R. B.: Toward an ecological classification of soil bacteria, Ecology, 88, 1354-1364, 2007.

Finer, L., Ohashi, M., Noguchi, K., and Hirano, Y.: Factors causing variation in fine root biomass in forest ecosystems, Forest Ecol. Manag., 261, 265-277, 2011.

Finzi, A., Sinsabaugh, R., Long, T., and Osgood, M.: Microbial Community Responses to Atmospheric Carbon Dioxide Enrichment in a Warm-Temperate Forest, Ecosystems, 9, 215-226, 2006

Fontaine, S., Mariotti, A., and Abbadie, L.: The priming effect of organic matter: a question of microbial competition?, Soil Biol. Biochem., 35, 837-843, 2003.

Fontaine, S., Bardoux, G., Abbadie, L., and Mariotti, A.: Carbon input to soil may decrease soil carbon content, Ecol. Lett., 7, 314320, 2004.

Fontaine, S., Henault, C., Aamor, A., Bdioui, N., Bloor, J. M. G., Maire, V., Mary, B., Revaillot, S., and Maron, P. A.: Fungi mediate long term sequestration of carbon and nitrogen in soil through their priming effect, Soil Biol. Biochem., 43, 86-96, 2011.

Gallardo, A. and Schlesinger, W. H.: Estimating microbial biomass nitrogen using the fumigation incubation and fumigation extraction methods in a warm-temperate forest soil, Soil Biol.
Biochem., 22, 927-932, 1990.

Gaudinski, J. B., Trumbore, S. E., Davidson, E. A., and Zheng, S. H.: Soil carbon cycling in a temperate forest: radiocarbon-based estimates of residence times, sequestration rates and partitioning of fluxes, Biogeochemistry, 51, 33-69, 2000.

Grayston, S. J., Vaughan, D., and Jones, D.: Rhizosphere carbon flow in trees, in comparison with annual plants: The importance of root exudation and its impact on microbial activity and nutrient availability, Appl. Soil Ecol., 5, 29-56, 1997.

Griffiths, B. S.: A comparison of microbially-feeding nematoes and protozoa in the rhizosphere of different plants, Biol. Fert. Soils, 9, 83-88, 1990.

Guenet, B., Danger, M., Abbadie, L., and Lacroix, G.: Priming effect: bridging the gap between terrestrial and aquatic ecology, Ecology, 91, 2850-2861, 2010.

Hamer, U. and Marschner, B.: Priming effects in different soil types induced by fructose, alanine, oxalic acid and catechol additions, Soil Biol. Biochem., 37, 445-454, 2005.

Harden, T., Joergensen, R. G., Meyer, B., and Wolters, V.: Soil microbial biomass estimated by fumigation extraction and substrate-induced respiration in 2 pesticide-treated soils, Soil Biol. Biochem., 25, 679-683, 1993.

Hedges, L. V. and Olkin, I.: Statistical Methods for Meta-Analysis, Academic Press, Orlando, FL, 1985.

Hobbie, J. E. and Hobbie, E. A.: N-15 in symbiotic fungi and plants estimates nitrogen and carbon flux rates in Arctic tundra, Ecology, 87, 816-822, 2006.

Hodge, A., Campbell, C. D., and Fitter, A. H.: An arbuscular mycorrhizal fungus accelerates decomposition and acquires nitrogen directly from organic material, Nature, 413, 297-299, 2001.

Jaeger, C. H., Lindow, S. E., Miller, S., Clark, E., and Firestone, M. $\mathrm{K}$.: Mapping of sugar and amino acid availability in soil around roots with bacterial sensors of sucrose and Tryptophan, Appl. Environ. Microbiol., 65, 2685-2690, 1999.

Janssens, I. A., Dieleman, W., Luyssaert, S., Subke, J. A., Reichstein, M., Ceulemans, R., Ciais, P., Dolman, A. J., Grace, J., Matteucci, G., Papale, D., Piao, S. L., Schulze, E. D., Tang, J., and Law, B. E.: Reduction of forest soil respiration in response to nitrogen deposition, Nat. Geosci., 3, 315-322, 2010.

Jones, D. L.: Organic acids in the rhizosphere - a critical review, Plant Soil, 205, 25-44, 1998.

Jones, D. L. and Darrah, P. R.: Role of root derived organic-acids in the mobilization of nutrients from the rhizosphere, Plant Soil, 166, 247-257, 1994.

Jones, D. L., Prabowo, A. M., and Kochian, L. V.: Kinetics of malate transport and decomposition in acid soils and isolated bacterial populations: The effect of microorganisms on root exudation of malate under Al stress, Plant Soil, 182, 239-247, 1996.

Jones, D. L., Owen, A. G., and Farrar, J. F.: Simple method to enable the high resolution determination of total free amino acids in soil solutions and soil extracts, Soil Biol. Biochem., 34, 1893-1902, 2002.

Jones, D. L., Hodge, A., and Kuzyakov, Y.: Plant and mycorrhizal regulation of rhizodeposition, New Phytol., 163, 459-480, 2004.

Jones, D. L., Nguyen, C., and Finlay, R. D.: Carbon flow in the rhizosphere: carbon trading at the soil-root interface, Plant Soil, 321, 5-33, 2009.

Kaiser, C., Koranda, M., Kitzler, B., Fuchslueger, L., Schnecker, J., Schweiger, P., Rasche, F., Zechmeister-Boltenstern, S., Ses- 
sitsch, A., and Richter, A.: Belowground carbon allocation by trees drives seasonal patterns of extracellular enzyme activities by altering microbial community composition in a beech forest soil, New Phytol., 187, 843-858, 2010.

Kaiser, C., Fuchslueger, L., Koranda, M., Gorfer, M., Stange, C. F., Kitzler, B., Rasche, F., Strauss, J., Sessitsch, A., ZechmeisterBoltenstern, S., and Richter, A.: Plants control the seasonal dynamics of microbial $\mathrm{N}$ cycling in a beech forest soil by belowground C allocation, Ecology, 92, 1036-1051, 2011.

Koch, A. L.: The macroeconomics of bacterial growth, in: Bacteria in their Natural Environments, edited by: Fletcher, M. and Floodgate, G. D., Academic Press, London, 1-42, 1985

Koroljova-Skorobogatko, O. V., Stepanova, E. V., Gavrilova, V. P., Morozova, O. V., Lubimova, N. V., Dzchafarova, A. N., Jaropolov, A. I., and Makower, A.: Purification and characterization of the constitutive form of laccase from the basidiomycete Coriolus hirsutus and effect of inducers on laccase synthesis, Biotechnol. Appl. Bioc., 28, 47-54, 1998.

Krashevska, V., Maraun, M., Ruess, L., and Scheu, S.: Carbon and nutrient limitation of soil microorganisms and microbial grazers in a tropical montane rain forest, Oikos, 119, 1020-1028, 2010.

Kuzyakov, Y.: Priming effects: Interactions between living and dead organic matter, Soil Biol. Biochem., 42, 1363-1371, 2010.

Kuzyakov, Y., Friedel, J. K., and Stahr, K.: Review of mechanisms and quantification of priming effects, Soil Biol. Biochem., 32, 1485-1498, 2000.

Kuzyakov, Y., Hill, P. W., and Jones, D. L.: Root exudate components change litter decomposition in a simulated rhizosphere depending on temperature, Plant Soil, 290, 293-305, 2007.

Langley, J. A., McKinley, D. C., Wolf, A. A., Hungate, B. A., Drake, B. G., and Megonigal, J. P.: Priming depletes soil carbon and releases nitrogen in a scrub-oak ecosystem exposed to elevated $\mathrm{CO}_{2}$, Soil Biol. Biochem., 41, 54-60, 2009.

Lavoie, M., Mack, M. C., and Schuur, E. A. G.: Effects of elevated nitrogen and temperature on carbon and nitrogen dynamics in Alaskan arctic and boreal soils, J. Geophys. Res.-Biogeo., 116, G03013, doi:10.1029/2010JG001629, 2011.

Lipson, D. A., Schmidt, S. K., and Monson, R. K.: Links between microbial population dynamics and nitrogen availability in an alpine ecosystem, Ecology, 80, 1623-1631, 1999.

Littell, R. C., Stroup, W. W., and Freund, R. J.: Analysis of Variance for Balanced Data, in: SAS for Linear Models, SAS Institute Inc., Cary, North Carolina, 33-90, 2002.

Lovett, G. M., Weathers, K. C., and Arthur, M. A.: Control of nitrogen loss from forested watersheds by soil carbon: Nitrogen ratio and tree species composition, Ecosystems, 5, 712-718, 2002.

Moorhead, D. L., Lashermes, G., and Sinsabaugh, R. L.: A theoretical model of $\mathrm{C}$ - and $\mathrm{N}$-acquiring exoenzyme activities, which balances microbial demands during decomposition, Soil Biol. Biochem., 53, 133-141, 2012.

Munger, J. W. and Wofsy, S.: EMS - Canopy-atmosphere exchange of carbon, water, and energy, Harvard Forest Data Archive, HF004, 1999.

Parton, W. J., Stewart, J. W. B., and Cole, C. V.: Dynamics of C, N, $\mathrm{P}$, and $\mathrm{S}$ in grassland soils - a model, Biogeochemistry, 5, 109$131,1988$.

Parton, W. J., Scurlock, J. M. O., Ojima, D. S., Gilmanov, T. G., Scholes, R. J., Schimel, D. S., Kirchner, T., Menaut, J. C., Seastedt, T., Moya, E. G., Kamnalrut A., and Kinyamario, J. I.: Observa- tions and modeling of biomass and soil organic-matter dynamics for the grassland biome worldwide, Global Biogeochem. Cy., 7, 785-809, 1993.

Paterson, E.: Importance of rhizodeposition in the coupling of plant and microbial productivity, Eur. J. Soil. Sci., 54, 741-750, 2003.

Perakis, S. S. and Hedin, L. O.: Fluxes and fates of nitrogen in soil of an unpolluted old-growth temperate forest, southern Chile, Ecology, 82, 2245-2260, 2001.

Phillips, R. P. and Fahey, T. J.: Patterns of rhizosphere carbon flux in sugar maple (Acer saccharum) and yellow birch (Betula allegheniensis) saplings, Global Change Biol., 11, 983-995, 2005.

Phillips, R. P. and Fahey, T. J.: Tree species and mycorrhizal associations influence the magnitude of rhizosphere effects, Ecology, 87, 1302-1313, 2006.

Phillips, D. A., Fox, T. C., and Six, J.: Root exudation (net efflux of amino acids) may increase rhizodeposition under elevated $\mathrm{CO}_{2}$, Global Change Biol., 12, 561-567, 2006.

Phillips, R. P., Bernhardt, E. S., and Schlesinger, W. H.: Elevated $\mathrm{CO}_{2}$ increases root exudation from loblolly pine (Pinus taeda) seedlings as an N-mediated response, Tree Physiol., 29, 15131523, 2009.

Phillips, R. P., Finzi, A. C., and Bernhardt, E. S.: Enhanced root exudation induces microbial feedbacks to $\mathrm{N}$ cycling in a pine forest under long-term $\mathrm{CO}_{2}$ fumigation, Ecol. Lett., 14, 187-194, 2011.

Potter, C. S., Matson, P. A., Vitousek, P. M., and Davidson, E. A.: Process modeling of controls on nitrogen trace gas emissions from soils worldwide, J. Geophys. Res.-Atmos., 101, 13611377, 1996.

Pritsch, K. and Garbaye, J.: Enzyme secretion by ECM fungi and exploitation of mineral nutrients from soil organic matter, Ann. For. Sci., 68, 25-32, 2011.

Richardson, A. D. and O'Keefe, J.: Phenological differences between understory and overstory: a case study using the long-term Harvard Forest records, in: Phenology of Ecosystem Processes, edited by: Noormets, A., Springer, New York, 2009.

Robertson, G. P. and Groffman, P. M.: Nitrogen transformation, in: Biochemistry, and Ecology, edited by: Paul, E. A., Soil Microbiology, Springer, New York, NY, USA, 41-364, 2007.

Rosenberg, M. S., Adams, D. C., and Gurevitch, J.: Metawin: Statistical Software for Meta-Analysis: Version 2.0, Sinauer Associates Inc., Sunderland, MA, 2000.

Rovira, A. D.: Plant root exudates, Bot. Rev., 35, 35-56, 1969.

Rustad, L. E., Campbell, J. L., Marion, G. M., Norby, R. J., Mitchell, M. J., Hartley, A. E., Cornelissen, J. H. C., Gurevitch, J., and Gcte, N.: A meta-analysis of the response of soil respiration, net nitrogen mineralization, and aboveground plant growth to experimental ecosystem warming, Oecologia, 126, 543-562, 2001.

Ryan, P. R., Delhaize, E., and Jones, D. L.: Function and mechanism of organic anion exudation from plant roots, Annu. Rev. Plant Phys., 52, 527-560, 2001.

Saiya-Cork, K. R., Sinsabaugh, R. L., and Zak, D. R.: The effects of long term nitrogen deposition on extracellular enzyme activity in an Acer saccharum forest soil, Soil Biol. Biochem., 34, 13091315, 2002.

Savage, K. E. and Davidson, E. A.: Interannual variation of soil respiration in two New England forests, Global Biogeochem. Cy., 15, 337-350, 2001. 
Savage, K., Davidson, E. A., Richardson, A. D., and Hollinger, D. Y.: Three scales of temporal resolution from automated soil respiration measurements, Agr. Forest Meteorol., 149, 2012-2021, 2009.

Schimel, J. P. and Bennett, J.: Nitrogen mineralization: Challenges of a changing paradigm, Ecology, 85, 591-602, 2004.

Schlesinger, W. H. and Peterjohn, W. T.: Processes controlling ammonia volatilization from Chihuahuan desert soils, Soil Biol. Biochem., 23, 637-642, 1991.

Schimel, J. P. and Weintraub, M. N.: The implications of exoenzyme activity on microbial carbon and nitrogen limitation in soil: a theoretical model, Soil Biol. Biochem., 35, 549-563, 2003.

Seitzinger, S., Harrison, J. A., Bohlke, J. K., Bouwman, A. F., Lowrance, R., Peterson, B., Tobias, C., and Van Drecht, G.: Denitrification across landscapes and waterscapes: A synthesis, Ecol. Appl., 16, 2064-2090, 2006.

Shackle, V. J., Freeman, C., and Reynolds, B.: Carbon supply and the regulation of enzyme activity in constructed wetlands, Soil Biol. Biochem., 32, 1935-1940, 2000.

Smith, W. H.: Character and Significance of Forest Tree Root Exudates, Ecology, 57, 324-331, 1976.

Somers, E., Vanderleyden, J., and Srinivasan, M.: Rhizosphere bacterial signalling: A love parade beneath our feet, Crit. Rev. Microbiol., 30, 205-240, 2004.

Sorensen, P. L., Michelsen, A., and Jonasson, S.: Ecosystem partitioning of ${ }^{15} \mathrm{~N}$-glycine after long-term climate and nutrient manipulations, plant clipping and addition of labile carbon in a subarctic heath tundra, Soil Biol. Biochem., 40, 2344-2350, 2008.

Sterner, R. W. and Elser, J. J.: Biological Chemistry: Building Cells from Elements. In: Ecological Stoichiometry: The Biology of Elements from Molecules to the Biosphere, Princeton University Press, Princeton, NJ, 44-79, 2002.

Talbot, J. M., Allison, S. D., and Treseder, K. K.: Decomposers in disguise: mycorrhizal fungi as regulators of soil $\mathrm{C}$ dynamics in ecosystems under global change, Funct. Ecol., 22, 955-963, 2008.

Thomas, D. C., Zak, D. R., and Filley, T. R.: Chronic N deposition does not apparently alter the biochemical composition of forest floor and soil organic matter, Soil Biol.Biochem., 54, 7-13, 2012.

Treseder, K. K.: Nitrogen additions and microbial biomass: a metaanalysis of ecosystem studies, Ecol. Lett., 11, 1111-1120, 2008.

Treseder, K. K., Balser, T. C., Bradford, M. A., Brodie, E. L., Dubinsky, E. A., Eviner, V. T., Hofmockel, K. S., Lennon, J. T., Levine, U. Y., MacGregor, B. J., Pett-Ridge, J., and Waldrop, M. P.: Integrating microbial ecology into ecosystem models: challenges and priorities, Biogeochemistry, 109, 7-18, 2012.
Turpault, M. P., Gobran, G. R., and Bonnaud, P.: Temporal variations of rhizosphere and bulk soil chemistry in a Douglas fir stand, Geoderma, 137, 490-496, 2007.

Urbanski, S., Barford, C., Wofsy, S., Kucharik, C., Pyle, E., Budney, J., McKain, K., Fitzjarrald, D., Czikowsky, M., and Munger, J. W.: Factors controlling $\mathrm{CO}_{2}$ exchange on timescales from hourly to decadal at Harvard Forest, J. Geophys. Res.-Biogeo., 112, G02020, doi:10.1029/2006JG000293, 2007.

Vance, E. D. and Chapin, F. S.: Substrate limitations to microbial activity in taiga forest floors, Soil Biol. Biochem., 33, 173-188, 2001.

Vilchez, S., Molina, L., Ramos, C., and Ramos, J. L.: Proline catabolism by Pseudomonas putida: Cloning, characterization, and expression of the put genes in the presence of root exudates, J. Bacteriol., 182, 91-99, 2000.

Vitousek, P. M. and Melillo, J. M.: Nitrate Losses From Disturbed Forests: Patterns and Mechanisms, Forest Sci., 25, 605-619, 1979.

von Stockar, U., Maskow, T., Liu, J. S., Marison, I. W., and Patino, R.: Thermodynamics of microbial growth and metabolism: An analysis of the current situation, J. Biotechnol., 121, 517-533, 2006.

Wallenstein, M. D., McNulty, S., Fernandez, I. J., Boggs, J., and Schlesinger, W. H.: Nitrogen fertilization decreases forest soil fungal and bacterial biomass in three long-term experiments, Forest Ecol. Manag., 222, 459-468, 2006.

Watanabe, K. and Hayano, K.: Seasonal-variation of soil protease activities and their relation to proteolytic bacteria and Bacillus spp. in paddy field soil, Soil Biol. Biochem., 27, 197-203, 1995.

Yamasaki, A., Tateno R., and Shibata, H.: Effects of carbon and nitrogen amendment on soil carbon and nitrogen mineralization in volcanic immature soil in southern Kyushu, Japan, J. For. Res.Jpn., 16, 414-423, 2011.

Zak, D. R., Groffman, P. M., Pregitzer, K. S., Christensen, S., and Tiedje, J. M.: The vernal dam- Plant microbe competition for nitrogen in Northern hardwood forests, Ecology, 71, 651-656, 1990.

Zimmermann, M., Leifeld, J., Schmidt, M. W. I., Smith, P., and Fuhrer, J.: Measured soil organic matter fractions can be related to pools in the RothC model, Eur. J. Soil. Sci., 58, 658-667, 2007.

Zwart, K. B., Kuikman, P. J., and van Veen, J. A.: Rhizosphere protozoa: their significance in nutrient dynamics, in: CAB International, edited by: Darbyshire, J. F., Soil protozoa, Wallingford, UK, 93-122, 1994. 